\title{
Value Modernisation in Central and Eastern European Countries: How Does Inglehart's Theory Work?*
}

\author{
BEATRICE CHROMKOVÁ MANEA and LADISLAV RABUŠIC** \\ Faculty of Social Studies, Masaryk University, Brno
}

\begin{abstract}
An intergenerational shift from more pro-family norms to individual-choice norms has been taking place since the 1980s. Conditions of economic and social security positively contributed to this shift especially in high-income countries. In this paper, we study the modernisation change on value structures in selected Central and Eastern European countries and compare them with Western European ones and look at the generational differences. We first check whether the value shift is moving in the assumed direction and whether it is copying trends observed in Western European countries. We then look at different generations to determine whether the younger generations in CEE countries that grew up after 1989, in a time of rapid economic and political change, show higher levels of post-materialist and post-modern values than the generations socialised and raised during the communist regime. We use data collected by the international repeated cross-sectional European Values Study (EVS). The results are not clear-cut on whether socioeconomic modernisation has led to higher shares of post-materialism, more genderegalitarian attitudes, and stronger support for individual-choice norms in CEE countries. In all the spheres of cultural modernisation analysed we found differences in values and attitudes between generations: the older generations were always more traditional than the younger generations. This was not just true in the CEE countries, as the same trend was recorded in the Western European countries.
\end{abstract}

Keywords: value modernisation, individual-choice norms, pro-family norms, gender equality

Sociologický časopis/Czech Sociological Review, 2020, Vol. 56, No. 6: 699-740

https://doi.org/10.13060/csr.2020.033

\footnotetext{
* Acknowledgement: Funding for this research was provided by the Czech Science Foundation - project number GA17-02022S ‘Hodnotové změny v České republice z evropské a světové perspektivy’ (Evropský výzkum hodnot/Světový výzkum hodnot 1991-2017). We acknowledge suggestions by anonymous reviewers. The final version of the paper is ours, though, and the reviewers bear no responsibility for any errors and mistakes.

** Direct all correspondence to: Beatrice-Elena Chromková Manea, Department of Sociology, Faculty of Social Studies, Brno, email: manea@fss.muni.cz; Ladislav Rabušic, Faculty of Social Studies MU Brno, Department of Sociology, Joštova 10, Brno 602 00, rabu@fss. muni.cz.
} 


\section{Introduction}

It has now been more than thirty years since the countries of Central and Eastern Europe experienced the fall of communism in 1989, an event that launched a profound political, economic, and social transformation. Many citizens of these countries expected, after the collapse of the totalitarian regime, that their 'backward' societies would quickly embark on a path of modernisation and undergo rapid social changes that would bring about, in a relatively short time, primarily an improvement in living standards, but also a whole range of opportunities for free individual development. They were somewhat naive in this expectation, as social change, unlike political and economic changes, happens over the long term, requiring decades. Indeed, social change is strongly conditioned by changing values and value preferences. These are known to have considerable inertia, as people's basic value structures and preferences are shaped during their formative years, approximately between the ages of 10 and 25 . Once established, values and value preferences are part of a person's psychological structure and thus relatively resistant to change.

Nonetheless, the inertia of value structures does not mean that social (and cultural) change is not possible. It is possible, but it is mostly gradual, adaptive, and happens more 'through intergenerational population replacement than by the conversion of already socialized adults' [Inglehart 1997: 19]. Essential in this adaptation process is that new life strategies are more likely to be adopted by young population groups than by older ones [Inglehart and Welzel 2005: 23]. In this context, Abramson and Inglehart [1992] talk about generational replacement to describe how, in the process of modernisation, which generates feelings of relatively high economic and existential security, younger birth cohorts (generations) ${ }^{1}$ experience different existential conditions from the ones that shaped the older generations. Therefore, the value preferences of older and younger generations usually differ.

According to Inglehart and Welzel's [2005] understanding of modernisation, a society's values are closely correlated with its level of economic development, but are also linked to its cultural legacy. Therefore, as Inglehart and Baker [2000] maintain, cultural change is path-dependent. ${ }^{2}$ Although economic development

\footnotetext{
1 The term 'cohort' denotes a set of individuals who experienced some crucial stages of life at approximately the same time, such as marriage, school graduation, war, economic shifts. They are approximately the same age and share similar ideas, problems, and attitudes. In other words, they share similar cultural experiences. Social science also uses the term 'generation' ('social generation') in this sense. Demography uses the more accurate term 'birth cohort', meaning people born in the same time interval (e.g. 1946-1950, 19511954).

2 The same notion can be found elsewhere. For instance, Eisenstadt [2000: 2], in his analysis of the development of modernity, says that institutional and ideological patterns were in their development 'greatly influenced by specific cultural premises, traditions, and historical experiences'.
} 
tends to bring pervasive cultural changes, the fact that society has been historically shaped by different cultural phenomena has enduring effects on its development. Cultural heritage and its norms continue to shape values, but because of generational replacement their impact may vary for different generations.

In Inglehart's conceptualisations [1971, 1977], one of the first recorded signs of a value change in the modernisation of advanced societies was a shift from materialist values, favouring economic and social security, to post-materialist values, favouring individual autonomy and self-expression. This culture shift in advanced industrial societies [Inglehart 1990] is, however, 'just one component of an even broader shift from traditional to secular-rational values and from survival values to self-expression values that is transforming prevailing norms concerning religion, gender, and tolerance of out groups' [Inglehart, Ponarin and Inglehart 2017: 1317]. It is manifested as a declining respect for authority, an increasing emphasis on subjective well-being, increased sensitivity to environmental quality of life, greater choice in the areas of family arrangements and sexual norms, and increasing emphasis on gender equity.

In this paper, we study the effects of modernisation and intergenerational population change on value structures as outlined by Inglehart and his colleagues in selected countries in Europe. We focus first on materialist/post-materialist values; we then pursue values indicating gender equality; and finally we track individual-choice norms. We compare five Central and Eastern European countries (CEE countries - Czech Republic, Slovakia, Poland, Hungary, and Romania) with four Western European countries (Austria, France, the Netherlands, and Sweden). We first check whether the value shift goes in the assumed direction and whether it copies trends of Western European countries. We then look at whether there are any differences between generations. In other words, we shall check whether the younger generations of CEE countries that grew up after 1989, during times of rapid economic and political changes, show higher levels of post-materialist and post-modern values than the generations socialised and raised during the communist regime. In this endeavour, we make use of the data collected by the international repeated cross-sectional European Values Study (EVS). Our paper is descriptive and exploratory. ${ }^{3}$

\footnotetext{
${ }^{3}$ We are not aiming here to explicitly check whether possible generational differences are due to intergenerational replacement or historical period influence, as such an analysis (based on regression models) would require an integrated all-waves and countries dataset. There are two reasons why we do not explicitly explore generational differences. The first reason is that no such dataset had been released by the time of writing this paper. So far, there is a separate integrated data file for the 1991-2008, and an integrated data file for the 2017 wave (we worked with the 2nd release, selected countries). One can argue that we could have integrated these two data files for the purpose of our analysis. We decided not to do so as much would need to be done in order to harmonise the two datasets and errors and differences between our and the official version of the dataset could appear. However, we plan to run such an analysis for a future paper as soon as the integrated all-waves
} 
The article is organised as follows. First, we briefly discuss theories dealing with issues of value modernisation/post-modernisation. Then, we explain the choice of countries that are compared in our analysis. We introduce our data and methods and then go on to present the main descriptive results for our variables and show how each analysed value indicator varies by generation and by country. We close with a discussion of the empirical results.

\section{Theoretical background and past research}

The focus of our paper is whether, in line with the theory of modernisation/ post-modernisation, we find value shifts among CEE countries after 1990 that are more or less similar to those observed in Western European countries since the 1970s.

\section{Post-materialism and individualisation}

Ronald Inglehart introduced and expanded the concept of post-materialist values [see Inglehart 1971, 1977, 1990, 1997, 2018]. He has discussed it in connection with cultural changes and reflexive modernisation. According to Inglehart, the ranking of human values reflects the socioeconomic conditions in which people have been raised; he terms this observation the 'scarcity hypothesis'. ${ }^{4}$ People who grew up during the First World War or during the Great Depression were more concerned about materialistic values related to security and well-being. The generations that were socialised after the Second World War were more likely to emphasise post-materialist values in various aspects of the quality of life, such as social justice or social tolerance. This is the effect of the 'socialisation hypothesis'. ${ }^{5}$

and countries dataset is released. That would allow us to better check the generational replacement assumption. Apart from data availability, we also had to take into account an analytical strategy that initially considered an APC analysis, which would allow us to simultaneously determine the effect of age, period and cohort. Aware of the pitfalls of using the APC analysis (as the effects of age, period, and cohort are linearly related) we considered working with an adjusted APC analysis model, like that proposed by Yang and Land [2008] - HAPC - that would partially eliminate the effect of the APC dependency. However, this method has a limitation that stems from the number of periods required for such an analysis. In our case, we have only four periods of measurement and it makes little sense to use HAPC with such a small number of periods.

4 'An individual's priorities reflect the socioeconomic environment: one places the greatest subjective value on those things that are in relatively short supply.' [Inglehart 1981: 881] 5 'The relationship between socioeconomic environment and value priorities is not one of immediate adjustment: a substantial time lag is involved, for, to a large extent, one's basic values reflect the conditions that prevailed during one's pre-adult years.' [Inglehart 1981: 881] 
When generation change occurs, post-materialist values are predicted to become the norm. Inglehart talks about the transformation of societies from 'traditional' to 'modern' (materialistic) and 'post-modern' (post-materialistic).

We are aware of the fact that Inglehart's post-materialist values and modernisation theory has generated criticism since it was introduced. ${ }^{6}$ Critics of the theory can be grouped into two major categories: the first line of criticism concerns whether modernisation and value changes have really occurred and whether they have occurred at the same pace; the second thread is focused on methodological and measurement issues relating to the way in which values are operationalised and measured. Rokeach [1973] was one of the first to criticise Inglehart's work by pointing to the 'ahistorical' character of Inglehart's theory. He argues that ' ... the equality-freedom orientation underlying the ideologies or political orientations selected for study here, it may be argued, can surely not be generalized to ideologies that prevailed a thousand years ago or to those that might prevail a thousand years hence' [ibid.: 186]. On the other hand, Flanagan [1980, 1982] and Flanagan and Lee [2003] focus their criticism on methodological and measurement issues. Flanagan uses various survey data and analytical strategies to show the drawbacks of modernisation theory as developed and tested by Inglehart. Inglehart [1982] has responded to this criticism and tried to refute Flanagan's arguments. Van Deth [1983] is another scholar who raises measurement issues in the discussion of Inglehart's theory, criticising Inglehart's choice of items and time unreliability in response. Also, Hadenius and Teorell [2005] claim that there is no clear-cut distinction between correlation and casual effects in Inglehart and Wetzel's model.

The role of socialisation in shaping values is one of the main elements of Inglehart's modernisation theory. This aspect did not escape the critics either. Duch and Taylor [1993, 1994] tried to prove that socialisation and economic hardship during the socialisation period do not play as great a role in shaping values as Inglehart argued in his theory. Education, in their opinion, is the main determinant of value change. Inglehart and his colleague Abramson [1994] has responded to this criticism by arguing that Duch and Taylor do not work with cohorts that were born before the Second World War or were socialised and lived close to or during that time and could have experienced economic and social hardship.

Savelyev [2016] confirmed some of Inglehart's assumptions relating to socialisation and economic and population development. He proved that 'the ob-

\footnotetext{
${ }^{6}$ One of the authors of this article published an article for Czech readers already in 2000, in which he criticised the method of measuring post-materialism and in which he summarised the fundamental methodological criticism of international scholars [see Rabušic 2000]. Datler, Jagodzinski and Schmidt [2013: 908], who tested the validity of Inglehart's theories, maintain as far as the post-materialist index is concerned that 'the discussion of the index would fill a whole methodological textbook of insightful criticism and intriguing counterarguments'.
} 
served change in materialist values towards post-materialist in either West European or post-socialist societies is entirely due to demographic turnover with control for education was not confirmed' [ibid.: 283]. He also demonstrated that the spread and intensity of post-materialist and materialist values in Western and Central European European countries is determined by both cohort replacement and the within-cohort component effect.

Haller [2002: 152] points to three major critical issues relating to Inglehart's theory of modernisation: 'the relevance of theoretical assumptions; the problem of the definition and measurement of concepts; and the distinction between different levels of aggregation and analysis'. One of the main methodological problems he draws attention to is the misleading assumption that the aggregate-level effects are also found at the individual level.

Despite these criticisms, we have decided to reflect on Inglehart's work and to a certain extent use in our analyses the same procedures that Inglehart and his co-authors did in their work. We believe that results obtained in this way can have their own cognitive relevance and that they will allow us to assess whether the value trajectories that the countries of Central and Eastern Europe have followed over the past 25 years and continue to follow are similar to those in Western Europe countries. Datler, Jagodzinski and Schmidt [2013: 922], after all, concluded at the end of their critical analysis of Inglehart's methodology that 'owing to Ronald Inglehart we have an important theory of value change which helps us to understand the ongoing changes in attitudes and behavior in the west and east. His theory makes relatively clear predictions about what will happen in countries like China or India if the economic growth should continue'.

\section{Gender and gender roles}

Modernisation theory assumes that the perception of gender roles will change in the process of modernisation. Inglehart and Norris [2003: 10] argue that 'human development brings changed cultural attitudes toward gender equality in virtually any society that experiences the various forms of modernization linked with economic development'. The causes are well known: the level of women's education in Western European countries increased significantly in the second half of the 20th century; women also became increasingly involved in the paid labour market. This made women more economically and socially independent, which had a profound impact on their identity and life goals: unlike previous generations, marriage and procreation are not key points in their adult life. ${ }^{7}$ The

\footnotetext{
${ }^{7}$ In this context, demographers talk about a second demographic transition, which has manifested as increasing unmarried cohabitation, a deep drop in marriage and fertility rates, and a rise in divorce rates.
} 
traditional family model has changed from male breadwinner to dual-earning model. In the sphere of values, a systematic shift from traditional values towards more egalitarian gender roles has been observed.

The modernisation process had a different effect on gender roles in the former communist countries than in the West. The role of women and their equal position were among the most important elements of communist ideology. Since the broadly-based economy and the development of its industries in these countries needed a sizeable labour force, women helped fill this need in the second half of the 20th century. The female employment rate was (and still is) relatively high. Women also studied in larger numbers at high schools, so the share of women with a complete secondary education gradually increased. Despite these structural modernisation factors, however, the roles of women in everyday life did not change much, and the male breadwinner model persisted: the man earned money, and the woman, in addition to having a full-time job, still took full care of the household and children; this has been called the women's double-shift model. Marriage was the predominant form of partnership. Thus, despite modernising structural factors at the societal level, the perception of gender roles remained traditional in the communist countries.

In the 1990s, following the political and economic changes and the expansion of tertiary education in CEE countries, the high levels of women's education and high employment rates started to change the gender climate. Feminist influences and patterns from Western countries significantly contributed to this. Women were more widely heard in society, and gender roles and gender equity increasingly became part of the media discourse.

\section{Individual-choice norms}

In the theory of modernisation, the modernisation process goes hand in hand with the lesser influence of various institutions on the formation of individual norms, attitudes, and values. Therefore, in a (post)modern society in which individual freedom and decision-making are highly appreciated values, the justification for a certain behaviour may differ from the traditional justification. Thus, according to the theory of modernisation, people in post-modern societies can decide for themselves - without any social pressure - whether they approve of, for instance, abortion, homosexuality, divorce, or casual sex. Further, Inglehart, Ponarin and Inglehart [2017: 1314] hypothesise that the members of high-income societies experience an intergenerational shift from 'pro-fertility norms' (emphasising traditional gender roles and stigmatising any sexual behaviour not connected with reproduction) to 'individual-choice norms' (supporting gender equality and tolerance of non-traditional behaviour such as homosexuality) - and that this shift is currently occurring with exceptional speed and transforming the politics of gender and sexual orientation in high-income societies. 


\section{Generations and generational differences in values}

One of the main assumptions of modernisation theory is that the profound transformation of value structures and value preferences is a process in which important roles are played by the level of socioeconomic development and by a country's cultural legacy and its norms. Since every society is made up of a set of different generations that have been socialised in different socioeconomic conditions and different cultural milieus during their formative years, it is obvious that in times of dynamic social change the generational composition of the population will influence the perception of existing social norms and the attitudes towards these norms. As social change (modernisation) progresses, new value preferences - stemming from generational replacement - will prevail, while the original ones will fade away with the outgoing generations.

In the current literature, the contemporary living population is divided into four birth cohorts: veterans, baby boomers, Generation X, and Generation Y. These cohorts share a birth time as well as common traits that come from the significant life events that they have experienced in common and that shape their values. Individuals born between 1900 and 1945 are referred to as 'veterans'. The group of 'baby boomers' is defined as those born between 1946 and 1959. 'Generation $X^{\prime}$ are people born between 1960 and 1980. 'Generation Y' (also called Millennials) are people born between 1981 and 2000 [Hernaus and Pološki Vokić $2014] .{ }^{8}$ It is assumed that the characteristics of members in each group influence the way they view the world - social relationships, the family, work ethic, and behaviour - as well as their motivations, communication preferences, and how they manage change [e.g. Kupperschmidt 2000; Domeyer 2006; Durkin 2007; Glass 2007; Cates 2010; Venus 2011].

Veterans (also known as the silent generation) were shaped by both world wars and the Great Depression in the 1930s. They were born between 1900 and 1945. The wars and crisis events formed their beliefs. They place great emphasis on family values and they tended to stay in one job throughout their working life [PrincetonOne 2013].

Baby boomers (born 1946 to 1959) are named after the period of new prosperity that followed the Second World War, when the worldwide baby boom occurred. Western baby boomers created the 'hippie' culture in which, among other things, new norms of partnership and sexuality were formed. This generation brought about the protests of 1968. Eastern European baby boomers were born in the time of radical political and economic change from capitalism and democracy to communism and totalitarianism, during which communists seized power and nationalised private enterprises and companies. Czechoslovakia, Poland, and

\footnotetext{
8 The next generation is called 'Generation $Z^{\prime}$ (people born after year 2000). Since it is a value-evolving generation still in its formative period, we do not consider this generation in our paper.
} 
Yugoslavia had protests, mainly against the lack of freedom of speech and the violation of civil rights.

Generation X is represented by those born between 1960 and 1980. They are also called the 'Divorce Generation' and the 'Slacker Generation' [e.g. Hernaus and Pološki Vokić 2014]. Its members have borne the full weight of the second demographic transition, characterised by a decrease in nuptiality and an increase in unmarried cohabitation, a decrease in fertility and an increase in divorce. In CEE countries, on the other hand, this generation brought about the collapse of the communist regimes [PrincetonOne 2013]. Members of this generation experienced in full the dismantling of communism and its economic system.

Generation Y (Millennials) is represented by people born between 1981 and 2000. Generations $X$ and $Y$ differ culturally and especially in the timing of different stages/phases of life. They seem to have very different priorities and needs [Hernaus and Pološki Vokić 2014]. Generation Y grew up in a time of globalisation and the internet and in CEE countries were also the first to grow up in a time of freedom compared to previous recent generations. So far, this generation is relatively the most educated and technically proficient. Its members were brought up as self-confident individuals who place high demands on themselves and others. This may have to do with their postponement of life events at the family level (childbearing, marriage/partnership) and a later entry into the labour market.

\section{Country context}

The main aim of our paper is to compare the development of value preferences in CEE countries in the context of the modernisation developments that took place after 1990. In order to have a more complete picture of the development of these values, we compare developments in CEE countries with those in Western countries. As our analysis is based on data from international quantitative research, at the time of writing this article we were somewhat limited in the country selection by data availability. We needed countries for which we had research data covering the required period, from 1991 to $2017 .{ }^{9}$ For this reason, we chose the Czech Republic,, Slovakia, Hungary, Poland, and Romania as the proxies for CEE countries. For the Western countries, we chose Sweden, the Netherlands, France, and Austria because we have the necessary data and because they represent two different types of welfare regimes as conceptualised by Esping-Andersen [1990]. ${ }^{10}$

\footnotetext{
9 The reasons we work with the period from 1991 to 2017 are explained in the next part of the text.

${ }_{10}$ Sweden is a proxy for the Nordic regime (or the social democratic welfare-state regime). In this type of welfare regime public benefits are instituted as social rights and thus social insurance is universal, egalitarian, and relatively generous. This system emphasises maximising labour force participation and promotes gender equality and a large degree of income redistribution. France, the Netherlands, and Austria are proxies for a conserva-
} 
Table 1. GDP per capita, PPP (current international dollars) in CEE and Western countries in 1991 and 2017 (countries sorted by GDP in 1991)

\begin{tabular}{lcc}
\hline & 1991 & 2017 \\
\hline Czech Rep. & 11592 & 38489 \\
Slovakia & $7163^{*}$ & 30907 \\
Poland & 5913 & 30152 \\
Hungary & 8310 & 29529 \\
Romania & 4786 & 27191 \\
\hline
\end{tabular}

\begin{tabular}{lcc}
\hline & 1991 & 2017 \\
\hline Netherlands & 21732 & 55347 \\
Austria & 20110 & 54637 \\
Sweden & 20694 & 52739 \\
France & 18304 & 44826 \\
& & \\
\hline
\end{tabular}

Source: https://data.worldbank.org/.

Note: * Reference year $=1992$.

Given the way we conducted our exploratory analyses, we decided to limit the number of countries being compared. The Western countries we chose represent economically and culturally advanced societies, in which the process of postmodernisation is at a high level. ${ }^{11}$

Since 1989, the countries of Central and Eastern Europe have been going through an intensive process of modernisation and their level of economic development and the standard of living of their inhabitants have been gradually increasing. However, the selected CEE countries were quite varied at the beginning of their modernisation process (after 1990): not only did they differ in their level of socioeconomic development (especially in their industrialisation levels), they also varied by the pace of modernisation they experienced (for an illustration of this, see Tables 1 and 2).

tive corporatist regime. This model encourages family-based assistance; the main mode of social assistance is based on the principal of subsidiarity. Corporations play a decisive role in social assistance by means of their various social insurance funds (old-age pension, health, unemployment, accident insurance). Social insurance therefore excludes nonworking spouses. Family benefits tend to encourage motherhood. One could ask why we have not worked with Germany as Germany is regarded as the typical example (according to Esping-Andersen) of a corporatist welfare regime. The answer would be that Germany is a country where the distinction between former West and East Germany is still in many aspects present. For the clarity of our analyses we would have to distinguish between the two, which would increase the number of countries. For the same reason we have omitted Italy and Spain, which have a conservative welfare regime (but are sometimes referred to having the Mediterranean regime). The third welfare regime, the liberal (or Anglo-Saxon) model, is typical for the United Kingdom. Given its specificity and proximity to our CEE countries, we decided to exclude the UK from our analysis.

${ }_{11}$ An anonymous reviewer asked us what the comparison would have been like if other countries had been chosen. This is, of course, a very good question and we hope we shall be able to answer it in a future paper based on a fully integrated dataset for all waves and countries. 
Table 2. Human Development Index (rank in brackets) in CEE and Western countries in 1991 and 2017

\begin{tabular}{lcc}
\hline & 1991 & 2017 \\
\hline Slovakia & $0.734[34]$ & $0.854[37]$ \\
Czech Rep. & $0.726[40]$ & $0.888[27]$ \\
Poland & $0.711[45]$ & $0.868[33]$ \\
Hungary & $0.702[48]$ & $0.841[44]$ \\
Romania & $0.686[54]$ & $0.813[55]$ \\
\hline
\end{tabular}

\begin{tabular}{lll}
\hline & \multicolumn{1}{c}{1991} & \multicolumn{1}{c}{2017} \\
\hline Netherlands & $0.834[5]$ & $0.932[10]$ \\
Sweden & $0.818[9]$ & $0.935[8]$ \\
Austria & $0.799[16]$ & $0.912[20]$ \\
France & $0.790[18]$ & $0.890[27]$
\end{tabular}

Source: http://hdr.undp.org/en/data\#.

In 1991 Czechia had the highest economic performance among CEE countries, as measured here by GDP in PPP, followed by Hungary and Slovakia (see Table 1). Over the next 25 years the situation changed. The Czech Republic still had the highest level of economic performance in 2017, followed by Slovakia and Poland. Hungary and Romania had the slowest paces of economic development and also the lowest GDP among the countries analysed here. Although these countries increased their GDP from 1991 to 2017 several times over, they are still quite behind the selected Western countries. ${ }^{12}$

CEE countries also differed by level of human development (see Table 2). In 1991 Slovakia (43) and the Czech Republic (40) ranked highest on the Human Development Index among CEE countries; in 2018 the highest rank among CEE countries was occupied by the Czech Republic (which was on a level similar to France) and Poland. ${ }^{13}$ The difference between CEE and Western countries is not as great for this indicator as it is for GDP.

CEE countries also differed culturally in 1991, especially in the rate of religiosity (the populations of Romania, Poland, and Slovakia were the most religious; the Czech and Hungarian populations were the least so). There were also differences in the rate of gender equality, although it was relatively high in the public sphere in all CEE countries: this is a legacy of the communist regimes, in which gender equality was one of the (ideological) goals. Women were highly integrated in the labour market and they had universal access to education. ${ }^{14}$ On

\footnotetext{
${ }^{12}$ However, we should bear in mind that these countries are among the most developed ones in the world.

${ }_{13}$ The cut-off points are an HDI of less than 0.550 for low human development, $0.550-0.699$ for medium human development, 0.700-0.799 for high human development, and 0.800 or greater for very high human development. From this point of view, the CEE countries in 1991 had high human development (except for Romania, which had low human development). In 2018, all the CEE countries had very high human development.

${ }_{14}$ According to some scholars, CEE countries 'were in some dimensions forerunners in
} 
the other hand, it was still primarily women who were doing the child-rearing and household chores. Although gender equality was vehemently emphasised rhetorically, everyday reality was quite different.

\section{Data and methods}

The source of our data is the European Values Study (EVS), which is a large international comparative longitudinal survey that measures the indicators of value change/consistency in Europe. ${ }^{15}$ It has been carried out four times in many European countries: in 1991, 1999, 2008, and 2017. The data are well suited to our purpose because the survey's time series runs from 1991 to 2017, so we are able to follow the progress of the modernisation process over that period. In the CEE countries, 1991 can be seen as a certain base line, as the attitudes and values captured in this EVS wave represent value structures that more or less correspond to the value climate of the preceding communist society. In the subsequent waves $(1999,2008$, and 2017), the degree of modernisation should become more visible.

The EVS uses a standardised questionnaire that covers a wide variety of topics, ${ }^{16}$ including perceptions of life, gender roles, the family, religion, politics and society, national identity, and the environment. Questionnaire items make it possible to follow indicators that, according to Inglehart [1997] and Inglehart and Welzel [2005], are at the core of the modernisation process. In each country, a random probability sample scheme is used, and the sample is representative of the population aged 18 and older. ${ }^{17}$ The dataset was provided by the Data Archive for Social Sciences (DAS) of the GESIS - Leibniz Institute for the Social Sciences; data for 2017 come from the second release.

Our article is based on the central claim of Inglehart's modernisation theory that 'economic development is linked with coherent and, to some extent, predictable changes in culture and social and political life' [Inglehart and Baker 2000: 21]. It is also based on results by Inglehart [1977, 1990, 1997] and Inglehart and Welzel [2005] that showed that 'high levels of economic and physical security

terms of promoting equality' (see https://freepolicybriefs.org/tag/gender-inequality-in$\operatorname{dex} /)$.

${ }^{15}$ For further details, see http://www.europeanvaluesstudy.eu/.

${ }_{16}$ The methodology of data collection and questionnaire formation are quite strict and standardised at the international and national levels so that the comparability among countries and between waves is ensured.

17 As happens in surveys, despite our adherence to sampling procedures designed to ensure representativeness, the datasets in all waves were slightly biased; accordingly, we applied weighting schemes. We used post-stratification weights, based on the structure of the population with respect to age, gender, education, and region. The weighting of the samples was also undertaken in other participating countries in accordance with the EVS's centrally set methodological rules. 
are conducive to a shift from materialist to post-materialist values - and that this shift tends to make people more favorable to important social changes' [Inglehart, Ponarin and Inglehart 2017: 1314]. Since CEE countries have been undergoing dynamic economic and human development since 1990, we are interested in determining whether in the cultural sphere, that is, in the field of value preferences, these 'predictable changes' have been taking place. We monitor whether values are changing from traditional to secular-rational and from survival to selfexpression.

Inglehart, Ponarin and Inglehart [2017] work with both six- and three-item indexes of individual-choice norms, which include items measuring the acceptance of gender equality on the one hand and the acceptance of divorce, abortion, and homosexuality on the other. ${ }^{18}$ Given the diversity of meaning among the items, we decided to work with two separate categories of indexes: one measuring gender roles at both the individual and the societal level and one measuring individual-choice norms. We argue that the gender role items used in the EVS questionnaire ${ }^{19}$ measure attitudes towards gender roles and they do not reflect individual-choice norms. ${ }^{20}$ These indexes were used separately in our analysis and we did not entirely follow Inglehart and his colleagues' analytical strategy they used the six-item index in cross-sectional analyses and the three-item index in time-series analyses.

\section{Results}

\section{Post-materialism}

According to Inglehart and Welzel [2005], socioeconomic development is crucial, as it has an impact on people's existential conditions and their perception. They argue that socioeconomic development impacted modern societies in two phases: (1) industrialisation, which triggered cultural change by means of rationalisation, centralisation, bureaucratisation, and secularisation, and (2) post-industrialism, which led to an increasing emphasis on individualism, which is to say, an emphasis on individual freedom to make decisions about one's own life and about one's personal development. Post-materialist values are spreading, as is an emphasis on individual autonomy.

To track the evolution of post-materialism, we use Inglehart's operationalisation, which is based on two questions. Respondents are asked to choose the

\footnotetext{
${ }_{18}$ These three items (acceptance of divorce, abortion, and homosexuality) were used by Inglehart and his colleagues in their analysis [see Inglehart et al. 2017].

19 These items are also used in other internationally recognised studies such as ESS, GGS or PPA.

${ }^{20}$ See, for example, Beere [1990] or M. van der Horst [2014] for more on gender roles and attitudes towards gender roles.
} 
Figure 1. Share of post-materialists by country 1991-2017
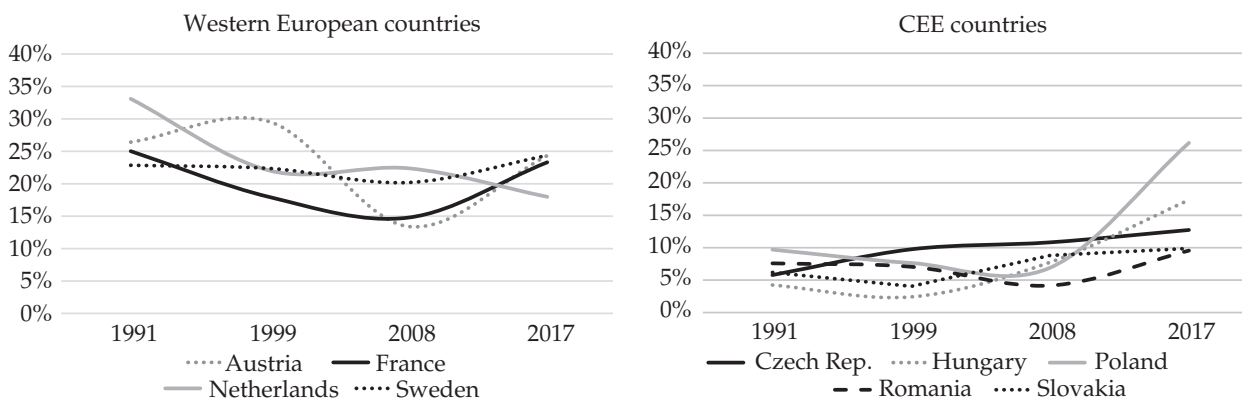

Source: EVS integrated 1981-2008 and EVS 2nd release EVS Cross-Sectional Data 2018.

first and second most important aims for their countries within the next ten years: Maintaining order in the nation, Giving people more say in important government decisions, Fighting rising prices, and Protecting freedom of speech. Respondents who choose items 2 and 4 indicate are 'post-materialists'; those who choose 1 and 3 are 'materialists'. A 'mixed' group captures any other combination.

In accordance with modernisation theory, we assume that (1) the share of post-materialists will gradually increase from 1991 to 2017 in CEE countries and that (2) it will remain lower than in Western countries. However, the difference should become smaller, as the CEE countries analysed here have become members of the European Union and that membership should have an unmistakably positive economic and political effect. We can also expect that (3) based on the socialisation hypothesis we will observe generational differences in post-materialism in which the youngest generations will be more post-materialistic than the oldest one. The distribution of post-materialism is presented in Figure 1.

As expected, the proportion of post-materialists in the CEE countries was low in 1991 and ranged between $4 \%$ and 10\%, with the lowest value in Hungary $(4 \%)$ and the highest in Poland (10\%). In the Western countries analysed, the share was higher, from 23\% in Sweden to 33\% in the Netherlands. However, by 2017 the curves considerably differed in the two groups of countries. In CEE countries (except Romania), in line with the modernisation theory, we see an increase in postmaterialism: from a moderate level in Slovakia (from 6\% to 10\%) and in the Czech Republic $(6 \%$ to $13 \%)$, to a considerable level in Hungary $(17 \%)$ and especially high in Poland (to 26\%). Interestingly, in the CEE countries, the share of 'mixed' people remained relatively stable (at 55\%-60\%) between 1991 and 2017, so the increase in post-materialism was at the expense of a reduction in materialism. This is also proved by Inglehart's Percentage Difference Index (PDI), which is calculated as the difference between the proportion of post-materialists and materialists. PDI values are shown in Table 3. The higher the value of this index, the higher the 
Table 3. Percentage Difference Index in CEE countries (the share of post-materialists minus the share of materialists)

\begin{tabular}{lcccc}
\hline & 1991 & 1999 & 2008 & 2017 \\
\hline Czech Rep. & $-26.3 \%$ & $-15.6 \%$ & $-18.6 \%$ & $-13.2 \%$ \\
Hungary & $-43.5 \%$ & $-48.1 \%$ & $-25.7 \%$ & $-10.9 \%$ \\
Poland & $-25.1 \%$ & $-29.3 \%$ & $-30.1 \%$ & $10.1 \%$ \\
Romania & $-37.5 \%$ & $-38.1 \%$ & $-34.7 \%$ & $-21.6 \%$ \\
Slovakia & $-33.3 \%$ & $-41.9 \%$ & $-22.4 \%$ & $-21.9 \%$ \\
\hline
\end{tabular}

Source: EVS integrated 1981-2008 and EVS 2nd release EVS Cross-Sectional Data 2018.

growth of post-materialists at the expense of materialists. In all the countries the PDIs changed significantly between 1991 and 2017: for example, in the Czech Republic in 1991 the proportion of post-materialists was 26 percentage points lower than the proportion of materialists; in 2017 it was only 13\%. In Poland we find that this index went from $-25 \%$ to $+10 \%$, which means that in 2017 the share of postmaterialists outnumbered the share of materialists by 10 percentage points.

In the Western countries, the trend in the proportion of post-materialists was unstable. The main finding, however, is that in the 1991-2017 period the share of post-materialists - except in the Netherlands - remained essentially the same in these countries, but the trajectories of development were different and fluctuating. In France, Austria, and Sweden (but not in the Netherlands), the share of post-materialists dropped in 2008 as a consequence of an economic crisis that affected the developed world, during which economic performance fell and unemployment increased. The theory of post-materialism takes this fluctuation into account. Inglehart admits that strong short-term fluctuations in economic development (short-term crises) can influence materialistic/post-materialistic attitudes [Inglehart 1981]. In these three countries, after 2008, the share of post-materialists rebounded in 2017, but it reached only the level observed in 1991. The situation in the Netherlands is, surprisingly, completely different. There was a decrease in the share of post-materialists, from 33\% in 1991 to 18\% in 2017. Moreover, during the crisis in 2008, the proportion of post-materialists did not decrease but slightly increased. We do not yet have an explanation for this trend and neither do our Dutch colleagues. $^{21}$

Interestingly, in the CEE countries the 2008 economic crisis did not de facto translate into a decrease in post-materialists (a slight decrease is observed, but it is in the standard error range). What is surprising is the big increase in the proportion of post-materialists in Poland between 2008 (7\%) and 2017 (26\%). In

${ }^{21}$ Personal communication by email with Loek Halman on 7 February 2020. 
Figure 2a. Share of post-materialists by HDI in 1991

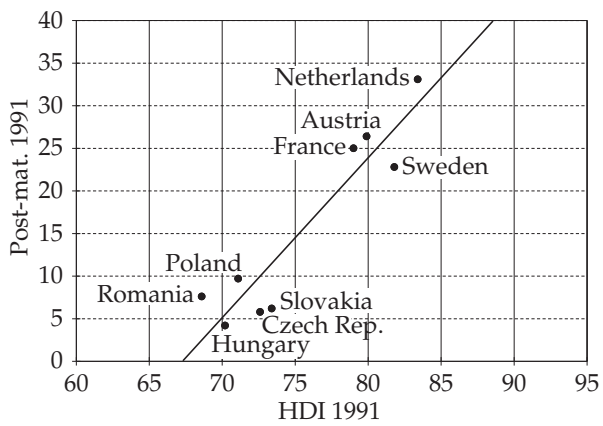

Figure $2 b$. Share of post-materialists by HDI in 2017

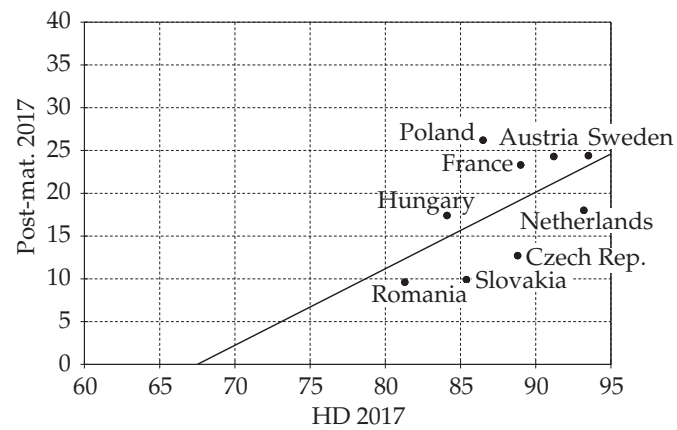

Source: EVS integrated 1981-2008 and EVS 2nd release EVS Cross-Sectional Data 2018. HDI from http://hdr.undp.org/en/data\# (see our Table 2) and for the purpose of this model the HDI values were multiplied by 100.

this respect, Poland reached a level comparable with that of Western European countries, although its GDP was approximately three times lower in 2017. It is likely that the fact that Poles greatly profited from their EU membership, which led to an improved standard of living and an overall sense of economic security, translated into their post-materialist attitudes. In addition, economic development is visible even to the casual observer in Poland: the appearance of cities and landscapes has obviously improved since 1991, which might also contribute to post-materialist feelings. It is likely that similar processes took place in Hungary, where the share of post-materialists had also increased substantially by 2017.

Compared to Poland (and to some extent Hungary), the share of postmaterialists in the Czech Republic and Slovakia is lower than might have been expected given their GDP and HDI levels. This most likely reflects the fact that Czechs and Slovaks had high expectations for a rapid increase in their standard of living after 1991. Although the standard of living has objectively increased, the reference framework for these two populations is the standard of living of their neighbouring countries, Germany and Austria (where it is very high). Czechs and Slovaks may therefore lean more towards materialism than post-materialism.

The theory of post-materialism assumes that with the overall humanistic development, the proportion of post-materialists in the population will also increase. We examined the data to see if this is the case. We use aggregated data from the Human Development Index (see Table 2) and the share of post-materialists in the population in 1991 and 2017. The results are shown in Figures 2a and 2b.

In 1991 there was a clear difference between the two groups of countries. The R-squared value (0.87) says that the linear model is a good approximation of 
reality, ${ }^{22}$ and the model says that as HDI increases the proportion of post-materialists also clearly increases. The parameters of the regression line say that with an increase in HDI by one unit, the proportion of post-materialists will increase by $1.9 \%$.

In 2017 the strength of the HDI's influence on the share of post-materialists was lower. Over time, the trend in CEE countries has converged overall with that in Western countries and the linear trend is no longer so clear (the R-squared has fallen to 0.33). If we model the relationship between HDI and post-materialism with a regression line (which is doubtful in this case), then the linear model says that with an increase in HDI by one unit, the proportion of post-materialists will increase by $0.9 \%$ only.

Generally speaking, these results could suggest that the pace of post-materialist growth in the population might tend to slow down once a certain level of humanistic development is reached. However, according to Inglehart, we should observe the opposite: he predicted in 1990 that as a result of modernisation, 'other things being equal, we will witness a long term trend towards post-materialist values as one generation replaces another' [Inglehart 1990: 87]. However, Figure 1 shows that this is not the case, since the post-materialist rates in Western countries remained essentially the same between 1991 and 2017.

In accordance with Inglehart's socialisation hypothesis, are there different proportions of post-materialists in the generations defined above? In other words, how is the development of post-materialism reflected in generational change? In line with the previous delineation, we follow the development of post-materialism in four generations separately in each country. Figure 3 presents the crossgenerational differences in post-materialism in each country.

In the CEE countries (except Poland), in accordance with the theory of socialisation, the youngest generation, Generation Y (1981-2000), had the highest proportion of post-materialists in 2017 among all the generations analysed. In Poland, it was Generation X (1960-1980). It is also true that in all CEE countries the oldest generation, the Veterans (born before 1945), had the lowest proportion of post-materialists. However, there are certain differences among CEE countries: in Hungary and Poland there was a steep increase in the rate of post-materialism in all generations after 1999. In Romania and Slovakia, there was a low and steady share of post-materialism in all generations, except Generation Y. In the Czech Republic, there was a downward trend in post-materialism in the oldest generation and a small (almost negligible) increase among baby boomers and Generation Y.

As in the CEE countries, in the Western countries the youngest generation, Generation Y, has the highest proportion of post-materialists (expect in the Netherlands), while the oldest generation (Veterans) has the lowest proportion.

${ }^{22}$ We are aware that nine cases (countries) are not an ideal number for a regression analysis. Unfortunately, we were not able to obtain more data when we were writing this paper. 


\section{Figure 3. Post-materialists by generation 1991-2017 (\%)_first part}
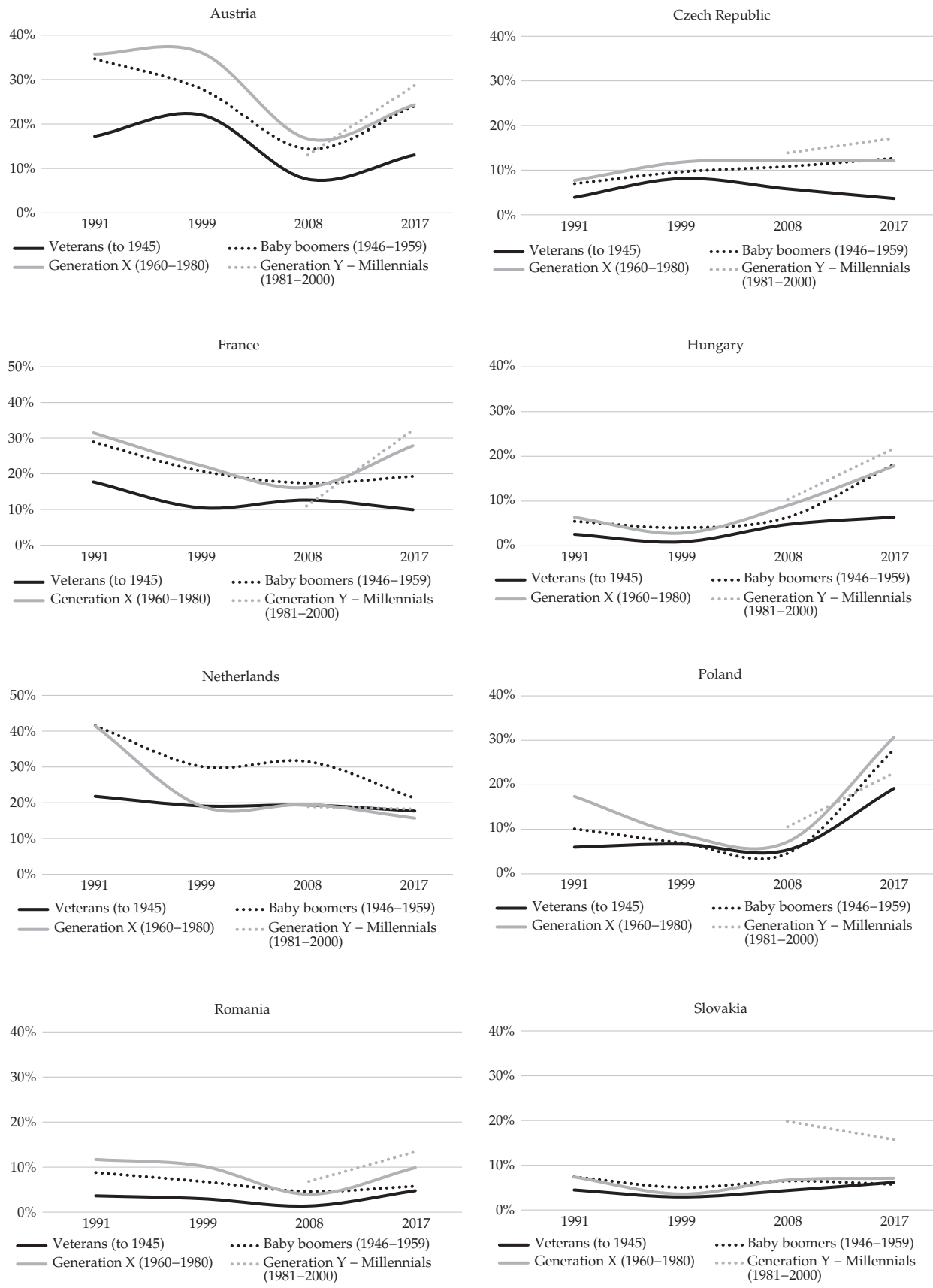
Figure 3. Post-materialists by generation 1991-2017 (\%)—second part

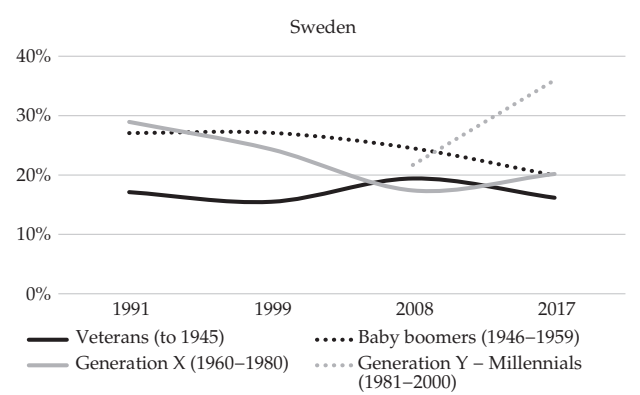

Source: EVS integrated 1981-2008 and EVS 2nd release EVS Cross-Sectional Data 2018. Difference to $100 \%$ are those who are materialists or mixed. Data for Generation Y only for 2008 and 2017 (no or low number of cases for 1991 and 1999).

However, the data for 1991-2017 do not show what Inglehart [1990: 87] suggested - namely, differences between the value priorities of individual generations and their relative stable positions. Moreover, the data do not reflect the trends that he predicted would result from the influence of the economic crisis: he argued that after an economic crisis, which leads to a decrease in the proportion of postmaterialists in all generations, the trends return to their original path. ${ }^{23}$ The only country in which post-materialism increased again after the 2008 crisis was Austria and - but only partly - France. Among CEE countries, this trend applies only to Poland and, to some extent, Hungary.

Summing up the above trends in the development of post-materialism in terms of modernisation theory, it can be stated that data from CEE countries partially confirm its validity:

(1) With the economic and social modernisation of these countries, the share of post-materialists gradually increased, so that the levels were higher in 2017 than in 1991. However, given the dynamic modernisation of the Czech Republic and Slovakia, as indicated by both GDP and HDI levels, we would expect much higher proportions of post-materialists than 13\% and 10\%, respectively, in 2017.

(2) In Western countries, despite the economic and humanistic development, the share of post-materialists did not increase significantly between 1991 and 2017, and the values in 2017 were close to those in 1991 (Sweden 23\%:24\%, Austria 26\%:24\%, France 25\%:23\%); in the Netherlands it even decreased $(33 \%: 18 \%)$. The share of post-materialists in CEE countries were on average as expected, generally lower than in the Western European countries. However, the difference gradually decreased. In 1991, the proportion of post-materialists was on average $7 \%$ in the CEE countries and $27 \%$ in the Western countries - a difference of 20 percentage points; in 2017, the shares were 15\% in the CEE countries and $23 \%$ in the Western European countries - an 8 percentage point difference.

${ }^{23}$ Inglehart [1990] found this from data that included an economic crisis in the mid-1970s (caused by the 1973 oil crisis). 
The big question here is whether measuring post-materialism with a 4-item battery does not mean that, from a certain level of economic and social/cultural development, the shares of post-materialists in the entire population will become saturated and stabilise at $25-30 \%$ and will never reach a higher level.

(3) Our longitudinal CEE country data partially confirmed the assumption of intergenerational differences. We argue, however, that intergenerational differences may be due not only to the combination of population turnover but also to a period-contextual influence and a change in educational levels. ${ }^{24}$ The oldest generations in CEE countries, born before 1945, had the lowest proportion of post-materialists (except Slovakia), and the proportion in these countries remained more or less constant in the 1991-2017 period (Poland is an exception). The youngest generation, born in 1981-2000, had the highest proportion of post-materialists (but not in Poland). Slovakia behaves differently: the share of post-materialists does not differ between generations and there was no increase in the share of post-materialists in the youngest generation between 2008 and 2017, but a decrease - from the relatively high level of $20 \%$ in the crisis year 2008 to $16 \%$ in 2017 .

(4) The question we need to ask over our longitudinal data is whether Inglehart's optimism that the trend towards post-materialism in highly developed countries is universal, strong, and permanent is valid. Swedish, French, and Austrian EVS data show that even in the youngest generations the level of post-materialism did not reach above 36\% (Sweden; France 30\%) Moreover, Dutch data go against all modernisation assumptions, because the share of post-materialists in all the generations there has been gradually decreasing since 1991 and stabilised at approximately $20 \%$ in 2017. In 2017 post-materialists outnumbered materialists by a mere 5 percentage points in Austria, by 2.5 in France, and by 1.4 in the Netherlands. Only in Sweden was this difference noticeable - at 25 percentage points.

\section{Attitudes towards gender roles}

Modernisation theory asserts that human development is associated with cultural shifts, which include, among others, cultural attitudes towards gender roles and gender equality. In any society that goes through modernisation based on economic development, 'modernization brings systematic, predictable changes in gender roles' [Inglehart and Norris 2003: 10]. The perception of and attitudes towards appropriate male and female roles in the family and society have in re-

\footnotetext{
${ }^{24}$ The expansion of higher education in former communist countries, particularly between 1999 and 2017, was quite substantial. According to OECD data, the share of the population with tertiary education aged 25-34 years rose from 11-14\% in the Czech Republic, Hungary, Poland and Slovakia in 1991 to 30-43\% in 2017. In Austria, France, the Netherlands, and Sweden the corresponding figures were $30-32 \%$ in 1999 and $40-48 \%$ in 2017. See https:// data.oecd.org/eduatt/population-with-tertiary-education.htm.
} 
Table 4. Gender Inequality Index in 2000 and 2017

\begin{tabular}{lll}
\hline & 1995 & 2017 \\
\hline Slovakia & 0.248 & 0.187 \\
Czech Rep. & 0.252 & 0.133 \\
Poland & 0.258 & 0.128 \\
Hungary & 0.322 & 0.270 \\
Romania & 0.471 & 0.316 \\
\hline
\end{tabular}

\begin{tabular}{lcc}
\hline & 1995 & 2017 \\
\hline Sweden & 0.090 & 0.043 \\
Netherlands & 0.114 & 0.044 \\
Austria & 0.186 & 0.078 \\
France & 0.199 & 0.058 \\
& & \\
\hline
\end{tabular}

Source: http://hdr.undp.org/en/data\#.

Note: Countries are ranked according to rates in 1995. In 1995, the lowest value in the world was calculated for Sweden (0.090), while in 2017 it was for Switzerland (0.040).

cent decades changed in many countries to such an extent that we could be so bold as to talk about a gender revolution. These changes include decreasing support for a rigid division of labour between husbands and wives, rising acceptance of married women's work, and a certain social pressure for men to increase their involvement in tasks traditionally performed by women such as caring for children and housework [Kalmijn 2003]. In other words, modernisation has had an eroding effect on traditional norms and created space for emerging new ones.

The Gender Inequality Index (GII) maps the effect of new female roles at a macro level. As a composite index, it is used to quantify the loss of achievement within a country that results from gender inequality. ${ }^{25}$ It ranges from 0 (no inequality in the included dimensions) to 1 (complete inequality) [Human Development Report 2010]. The GII is interpreted as a percentage and indicates the percentage of potential human development lost as a result of gender inequality. ${ }^{26}$ The trends in GII between 1995 (the earliest data we have) and 2017 are presented in Table 4.

The table shows that the CEE countries had higher values on the Gender Inequality Index in both compared years than the Western countries did. Nevertheless, in all the countries gender inequality decreased between 1995 and 2017,

\footnotetext{
25 The index was introduced in the Human Development Report 2010. It uses three dimensions to measure opportunity costs: reproductive health, empowerment, and labour market participation. The reproductive health dimension has two indicators: the maternal mortality ratio and the adolescent fertility rate, which measures early childbearing (teenage pregnancy). Empowerment is measured by two indicators: the share of parliamentary seats held by each sex and higher levels of educational attainment (secondary education and above). Labour market participation is measured by women's participation in the work force.

${ }^{26}$ For example, in 2017 the GII was 0.043 in Sweden - indicating a 4\% loss in potential human development due to gender inequality.
} 
Figure 4. Agreement with the statement 'women really want a home and children' by country 1991-2017 (\%)
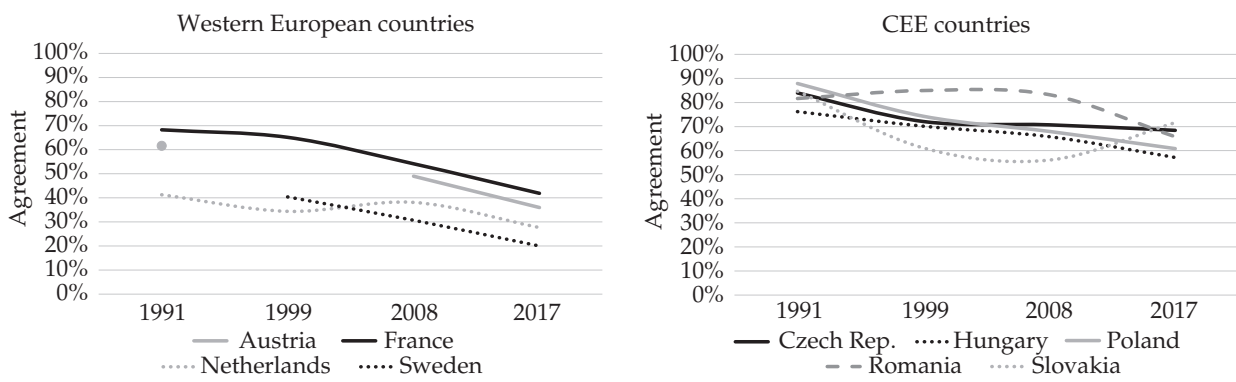

Source: EVS integrated 1981-2008 and the EVS 2nd release EVS Cross-Sectional Data 2018. This question was not asked in Austria in 1999 and in Sweden in 1991.

Note: Original 4-point scale. Categories 'agree strongly' and 'agree' recoded into 'agree'. The difference to $100 \%$ represents those who answered 'disagree'. Results in percentages.

as envisaged by the modernisation theory. Given that economic development (measured by GDP), human development (measured by HDI), and Gender Inequality (GII) indicate (see Tables 1, 2, and 5) the clear-cut existence of modernisation trends in CEE countries, we can expect also to see modernisation shifts in the domain of gender roles in our survey data.

To track trends in attitudes towards gender roles, we will use several indicators by which this phenomenon is usually measured. The first indicators measure conflicting gender roles (traditional vs modern) and look at how these conflicts are assessed at the individual level - for example, conflicts that may arise between work (public sphere) and the family (private sphere). The items are as follows: (1) A job is alright but what most women really want is a home and children and (2) When a mother works for pay, the child suffers. ${ }^{27}$ They were measured in the questionnaire using a 4-point scale, where 1 means fully agree and 4 means completely disagree. Figures 4 and 5 present the agreement rate for the two items for all countries and waves. ${ }^{28}$

The trends in the CEE countries since 1991 went in the expected direction. In 1991, the vast majority of the population believed in the dichotomy of work versus family - there was a clear preference for the idea that a woman needs a family and children: the highest share of agreement was found in Poland (94\%);

\footnotetext{
27 This question was phrased as follows in 1991, 1999, and 2008 as follows: A preschool child is likely to suffer if his or her mother works; while in 2017 it read: A child is likely to suffer if his or her mother works.

${ }^{28}$ Not all items were included in all waves. To illustrate development over time, we present only those items that were part of all waves.
} 
Figure 5. Agreement with the statement 'a (preschool) child suffers when mother works' by country 1991-2017 (\%)
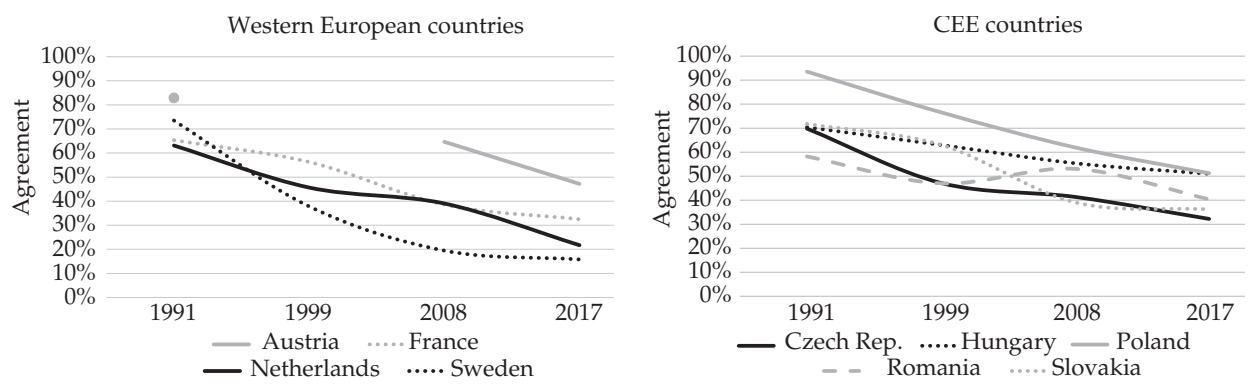

Source: EVS integrated 1981-2008 and EVS 2nd release EVS Cross-Sectional Data 2018. This question was not asked in Austria in 1999.

Note: Original 4-point scale. Categories 'agree strongly' and 'agree' recoded into 'agree'. Difference to $100 \%$ represents those who answered 'disagree'. Results in percentages.

the lowest was in Romania (58\%). Until 2017, these shares linearly declined, except in Romania and Slovakia, where the decrease had a different trajectory but still reached a lower level in 2017 than in 1991. Compared to Western European countries, however, CEE shares were considerably higher and by 2017 had still de facto only reached the level observed in Western countries in 1991, which is somewhat surprising. The most unexpected result is in Poland, where the biggest decrease was observed, even though there is a strong political emphasis on the family there. It is evident here that in this respect the gender revolution in CEE countries still has rather a long way to go. ${ }^{29}$

On the other hand, when we look at agreement with the statement 'the child suffers when the mother works' (see Figure 5), trends in the CEE countries are following a path towards gender equality: we see that the relatively high agreement rates in 1991 noticeably (de facto linearly) had decreased by 2017 (except in Romania, where the decline was not so straightforward). The feeling that a child suffers when its mother works was thus substantially weaker in 2017 than it was in 1991 and it had grown closer to the levels in Western countries. ${ }^{30}$ However, the

\footnotetext{
${ }^{29}$ We also looked at possible differences in agreement between men and women. For example, we found that in 2017, in four countries (Sweden, Austria, the Netherlands, and Poland), women agreed less with this statement than men did. There are no significant differences between men and women in the other countries.

30 Again, we checked for possible differences between men and women. The results in 2017 show that there are differences between men and women: in France or Hungary, women agree more than men do that a child suffers when the mother works; in Austria, Sweden, the Netherlands, Poland, and Slovakia, men agree more than women do.
} 
question here is to what extent the very fact that in the CEE countries, generally speaking, families need women to have paid employment in order to ensure a certain standard of living of the household is the cause of the recorded disagreement with the statement or whether respondents are really persuaded that female paid work and child rearing are compatible. The linear downward trend in Western European countries in Figure 5 is not surprising and is another indicator of the level of gender revolution.

As both items are part of a more general gender role indicator, we decided to combine these two items into an indicator that distinguishes those who adhere to 'traditional gender roles' from those who embrace 'modern gender roles' or have 'mixed attitudes' ${ }^{31}$ From a semantic point of view, this index reflects respondents' attitudes towards a woman's paid work in the labour market and her role in the household. Figure 6 presents the share of those who endorse traditional gender roles, which is to say, those who think that women should take care of the family and not work. In the CEE countries, the proportions of proponents of traditional roles were relatively high in 1991 (with a wide range of difference: between $83 \%$ in Poland and $48 \%$ in Romania) compared to the Western countries, but after 1991 there is an almost linear decline, with a slight slowdown in the trend between 2008 and 2017. The drop between 1991 and 2017 is quite considerable. The proportion of proponents of traditional roles in 2017, at $30-45 \%$, approached the 2017 rates in the Western European countries, which ranged between $10 \%$ and $30 \%$. An exception to this model is Romania, which started in 1991 at a relatively low level (at $48 \%$, the lowest level), so the downward trend by 2017 was not so steep (34\%). Voicu and Voicu [2002] and Voicu [2008] argue that the presence of women in the labour market was a common reality during the communist regime as the government encouraged women to enter into paid employment and provided support for families, and for women especially, by ensuring enough childcare facilities. Thanks to this, the gender attitudes of Romanians were close to some Western European countries at the beginning of the 1990s. The situation changed after the fall of the communist regime when the government encouraged the transfer of childcare responsibilities from the state to the family and the number of childcare facilities decreased during the transition period. Romania, like other CEE countries, still lacks measures that could enable women to combine paid employment and a family, such as access to affordable childcare facilities and flexible working arrangements. This lack might have led to the withdrawal of support for female participation in paid work.

On the other hand, Poland is an example of how socioeconomic modernisation is reflected in attitude and value changes. The decline of the traditional gen-

\footnotetext{
${ }^{31}$ The exact algorithm for building the indicator is as follows: all those who answered 'agree' to both items were recoded as having traditional gender role attitudes; all those who disagreed with both were recoded as having modern gender role attitudes; the rest (any combination of agree/disagree on these two items) were recoded as having mixed attitudes.
} 
Figure 6. Index of traditional gender role attitudes by country 1991-2017 (\%)
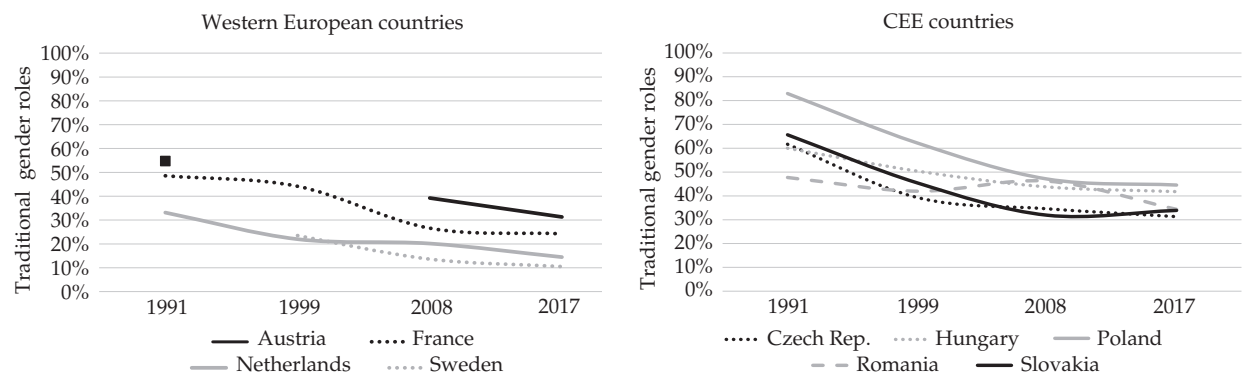

Source: EVS integrated 1981-2008 and EVS 2nd release EVS Cross-Sectional Data 2018. Some questions were not asked in Austria in 1999 or in Sweden in 1991.

Note: Indicator with 3 categories. The difference to 100\% represents those who have modern and mixed gender role attitudes. Results in percentages.

der model in Poland between 1991 and 2017 is breath-taking (from 83\% down to $45 \%$ ). In Western countries, the differences between countries are also sizable and there has been a downward linear trend. In 2017, the share of respondents who adhered to the traditional gender role model was the lowest in Sweden (11\%) and the Netherlands (15\%). Austria, at 31\%, was close to the Czech Republic and Slovakia in 2017.32

As far as intergenerational differences in the index of gender roles are concerned (see Figure 7), we made several observations. (1) There are generational differences in all CEE countries. The generation born before 1945 has the most traditional views, while Generation Y (Millennials) has modern views on conflicting gender roles. (2) Czechs and Slovaks have similar generational trajectories between 1991 and 2008. In 2017, however, the attitudes of all generations in Slovakia grew closer; the intergenerational gap in the Czech Republic remained unchanged in 2017, but the linear decline stopped. (3) In Poland, there was a strong decline in traditional gender attitudes in all generations in the 1991-2008 period. After that, in the two oldest generations, traditional gender attitudes gained

\footnotetext{
32 We also checked for differences between men and women. Generally speaking, they were relatively small in all the countries and were no greater than $10 \%$ [percentage points]. In 1991, men in the Czech Republic and France outnumbered women with traditional gender role responses by 9\% (Czech Republic) and 7\% (France). In 2017, the biggest differences between male and female respondents were in Austria (10\%), Poland (9\%), and Sweden (8\%). In Sweden, the difference was between $15 \%$ of men agreeing and $7 \%$ of women; in Poland it was between $49 \%$ of men and $40 \%$ of women. The only country in which women held substantially more traditional attitudes in 2017 was Hungary, where women were more traditional by 7 percentage points (45\%:38\%).
} 
Figure 7. Traditional gender role attitudes at the country level and by generation 1991-2017 (\%)—first part
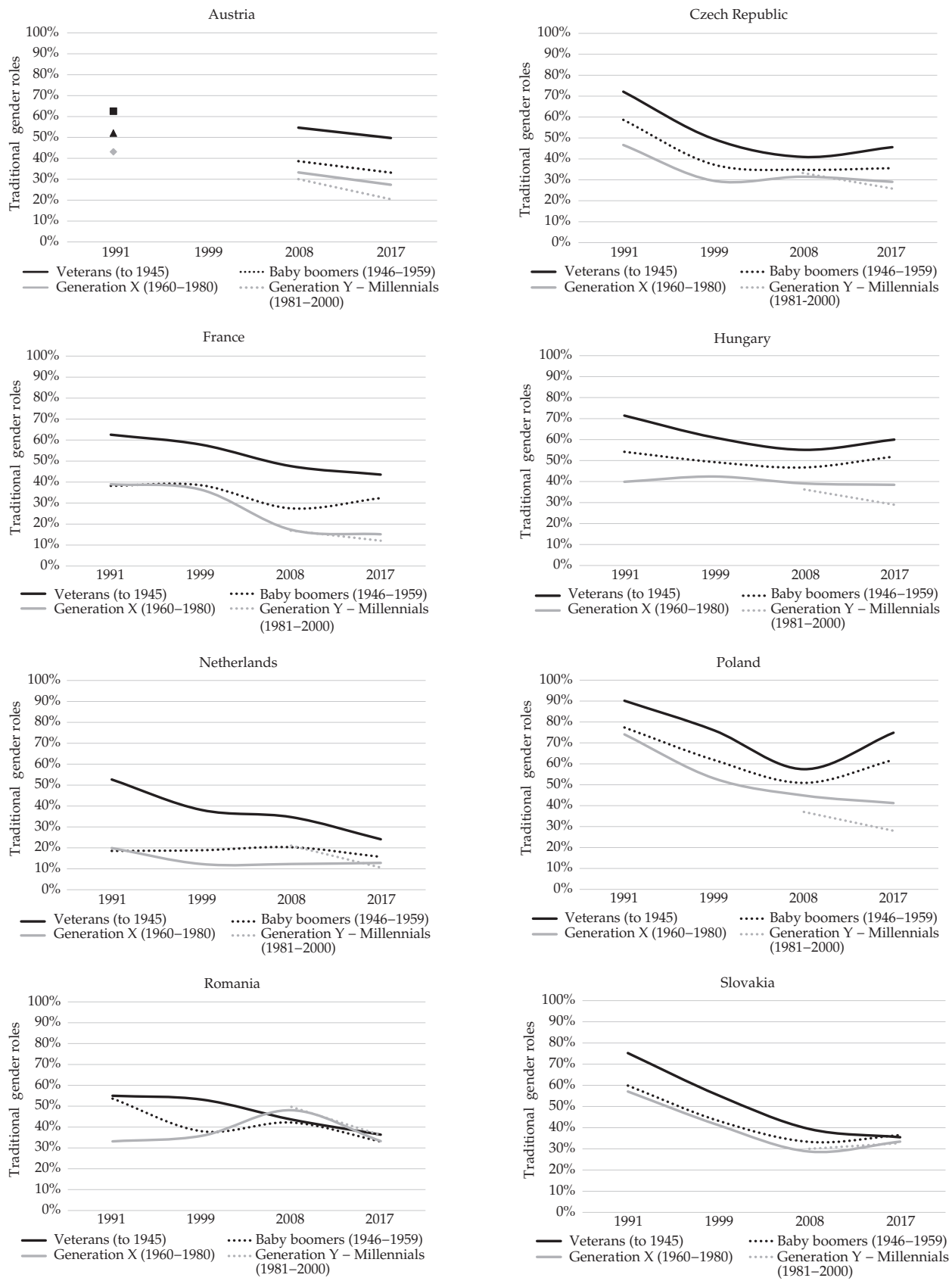
Figure 7. Traditional gender role attitudes at the country level and by generation 1991-2017 (\%)—second part

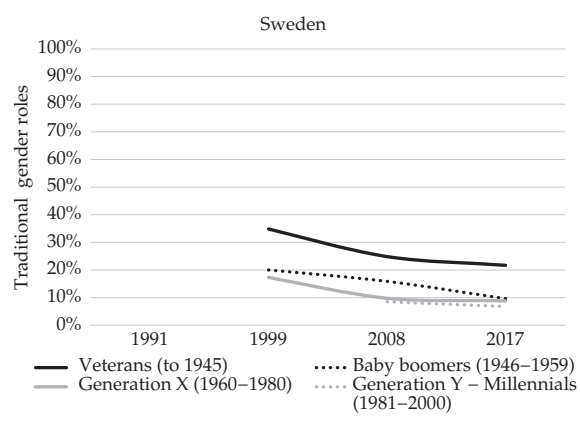

Source: EVS integrated 1981-2008 and EVS 2nd release EVS Cross-Sectional Data 2018. Data for Austria 1999 and Sweden 1991 not collected. Data for Generation Y only for 2008 and 2017.

strength, possibly due to the powerful ideological rhetoric of the ruling Law and Justice Party, as it endorses moral values linked to Polish traditionalism and the Catholic Church, which vigorously promotes traditional family values and opposes abortion, registered same-sex partnerships, and euthanasia. However, the youngest Polish generations maintained the downward trend. A similar pattern is found in Hungary. (4) In Romania, in contrast to the other CEE countries, there is no clear pattern and all the generations in 2017 moved closer to reaching relatively low values for traditional gender role attitudes.

In the Western European countries, the older generations have the highest share of traditional gender role attitudes. The two younger generations, with a very low proportion of respondents endorsing traditional gender role attitudes, are very similar in the Netherlands, Sweden, and France, though not in Austria. These results can be understood as an indicator that the Western generations born after 1960 have already internalised modern gender role attitudes in employment and family. From this point of view, it seems they are completing the gender revolution. The fact that female participation rates in the labour market (measured as the share of the female population aged 15+) in the Western countries analysed were gradually increasing in the 1991-2017 period surely contributed to this trend - the female employment rate in 2017 ranged between 50\% (France) and $61 \%$ (Sweden). In the CEE countries, the highest female employment rates in 2017 were in the Czech Republic and Slovakia (both about 53\%), and the lowest was in Romania (48\%).

In addition to gender attitudes towards employment and family, we can also use a set of indicators capturing attitudes towards gender segregation (gender stereotyping) at the societal level. Four items in the questionnaire measure this: (1) On the whole, men make better political leaders than women do; (2) A university education is more important for a boy than for a girl; (3) On the whole, men make better business executives than women do; and (4) When jobs are scarce, men have more right to a job than women. As these items were included only in 
Figure 8. Agreement with various statements on gender segregation on societal level in $2017(\%)$
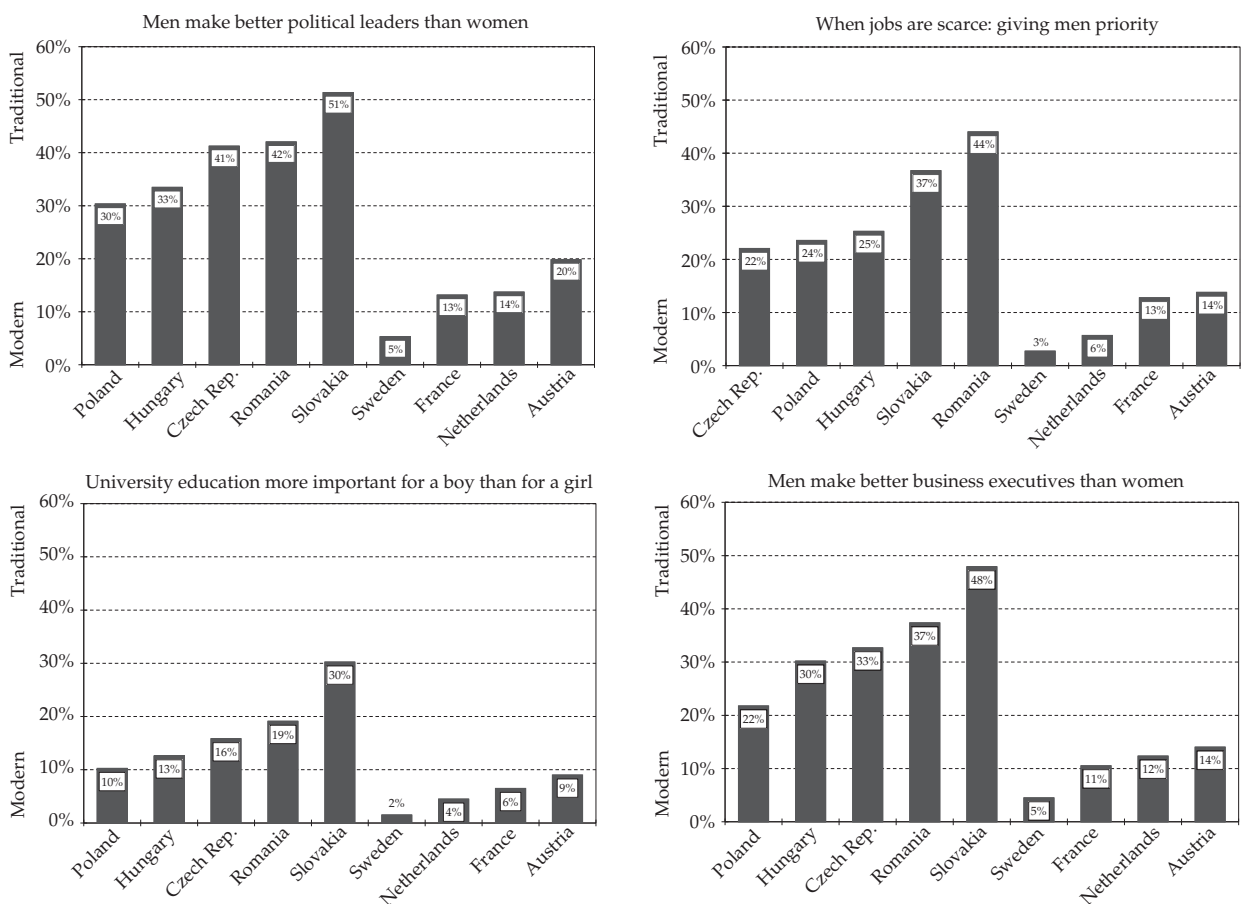

Source: EVS 2nd release EVS Cross-Sectional Data 2018.

Note: Original 4- or 5-point scale. The columns represent summaries of the response categories 'agree strongly' and 'agree'. The higher the agreement, the more traditional the attitude.

the 2017 EVS survey, we cannot provide the long-term trends. Nevertheless, the 2017 snapshot is very interesting. Figure 8 shows the distributions.

Within all these items measuring gender segregation on a societal level, there is a clear-cut difference between the CEE and the Western European countries. The populations of CEE countries have a much higher level of traditional gender attitudes (even stereotypes) than the Western countries do. Slovakia and Romania appear to be the most traditional, while surprisingly the least traditional seems to be Poland. In the Western European countries, there is a very low share of agreement with all of these statements; the low numbers in Sweden are very surprising. The fact that a significant proportion of respondents in the CEE countries think that men make better political leaders than women, that men should be favoured for jobs in times of high unemployment, and that men are better executives than women indicates that at a societal level people's minds are still 
bound to a gender-stereotype model. It reflects the fact that in these countries, there are still few women active in political life and as managers in top positions.

A much larger proportion of respondents in the CEE countries than in the Western European countries agree that men should have priority in getting a job when jobs are scarce, suggesting that the breadwinner family model is still preferred. The lowest share of agreement is found for the item concerning the importance of university education for boys and girls. This view, we think, partly reflects the educational expansion in former communist countries (see footnote 24). Women have begun to study in large numbers at universities and the share of women with higher education in the labour market has also increased. This indicator raises the question of the relationship between values/attitudes and behaviour. Is a relatively low level of agreement with the idea that university education is more important for boys than girls a result of many more women studying at a university, or is it because attitudes towards girls' education have positively changed within families so girls are motivated and supported to study at a university? The expansion of tertiary education that took place in all post-socialist countries with various intensity can be regarded as one of the social forces that shape values and attitudes. ${ }^{33}$ Duch and Taylor [1993] point out that each generation's experience of education in their formative years impacts their life attitudes and values and can be taken as an alternative explanation for intergenerational differences in values and attitudes.

As these and previous analyses show that populations in CEE countries are still more conservative in their gender attitudes than populations in Western countries, we can assume that there will be a bigger gender gap in CEE countries than in Western countries. Our results confirm this assumption. Neither of the aforementioned indicators exceeded the $10 \%$ difference between men's and women's responses in Western countries, which can be interpreted to mean that, at least verbally, men and women do not differ in these populations. In CEE countries, the situation is different.

(1) For all indicators, Slovak men significantly more often than Slovak women (both in statistical and substantive terms) agreed with the above statements (the difference between them was in each case greater than 10 percentage points and ranged between $13 \%$ and $24 \%$ ).

(2) Men in all the CEE countries (except Romania) were more likely than women to think that men make better political leaders than women do (the difference ranged between $11 \%$ and $24 \%$ ). Likewise, in all the CEE countries (including Romania), men are more likely than women to believe that men make better business executives than women do (here the difference ranged between $12 \%$ and $21 \%$ ).

\footnotetext{
${ }^{33}$ Mannheim [1952] advanced the social force perspective and argued that an individual's formative years form the background to his or her experience of life and the world and shape a person's attitudes and values.
} 
Figure 9. Index of gender segregation at a societal level in 2017 (means)

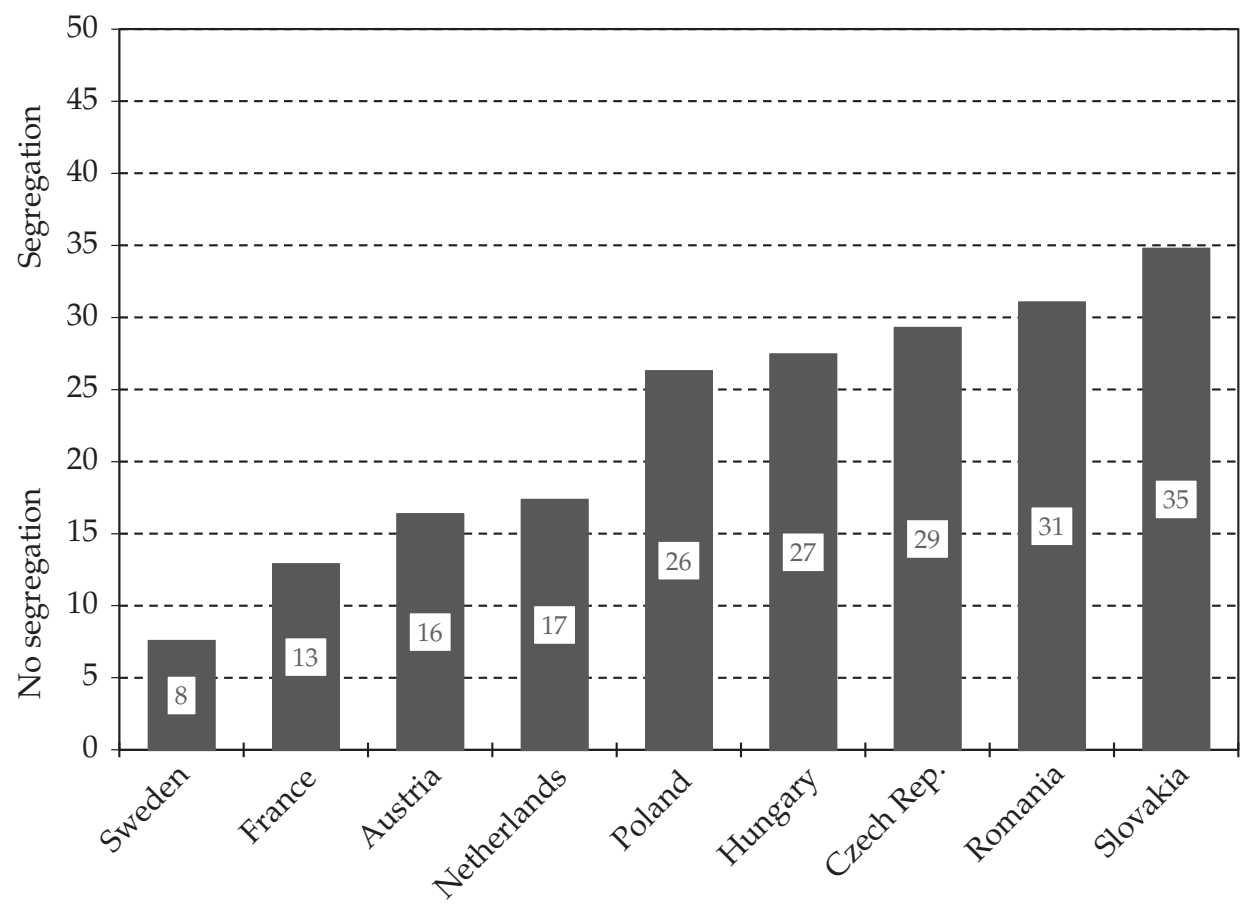

Source: EVS 2nd release EVS Cross-Sectional Data 2018.

Note: The index encompasses a range of values from 0 to 100 , where 0 means no societal segregation and 100 means full societal segregation. The Cronbach alpha in all the countries was at least 0.7 .

In all the countries, the indicator also points to clear differences in attitudes between the oldest and youngest generations (see Figure 10). The youngest generations (e.g. Millennials) expressed less support for societal segregation than the oldest ones (e.g. Veterans).

(3) The attitudes of men and women do not differ (except in Slovakia) - in both the Western and the CEE countries - on the importance of a university education for boys and girls. Similarly, there is no difference (again except in Slovakia) in the attitudes towards who should have priority in getting a job when there is unemployment. On the whole, in all the countries, men and women have the same attitudes about education and work for men and women. In contrast, the CEE countries differ from the Western countries on the role of men and women in policy and management. As Figure 8 shows, however, gender stereotypes are, even in 2017, still much stronger in the CEE countries than in the Western ones. 
Figure 10. Index of gender segregation at a societal level by generation (means)

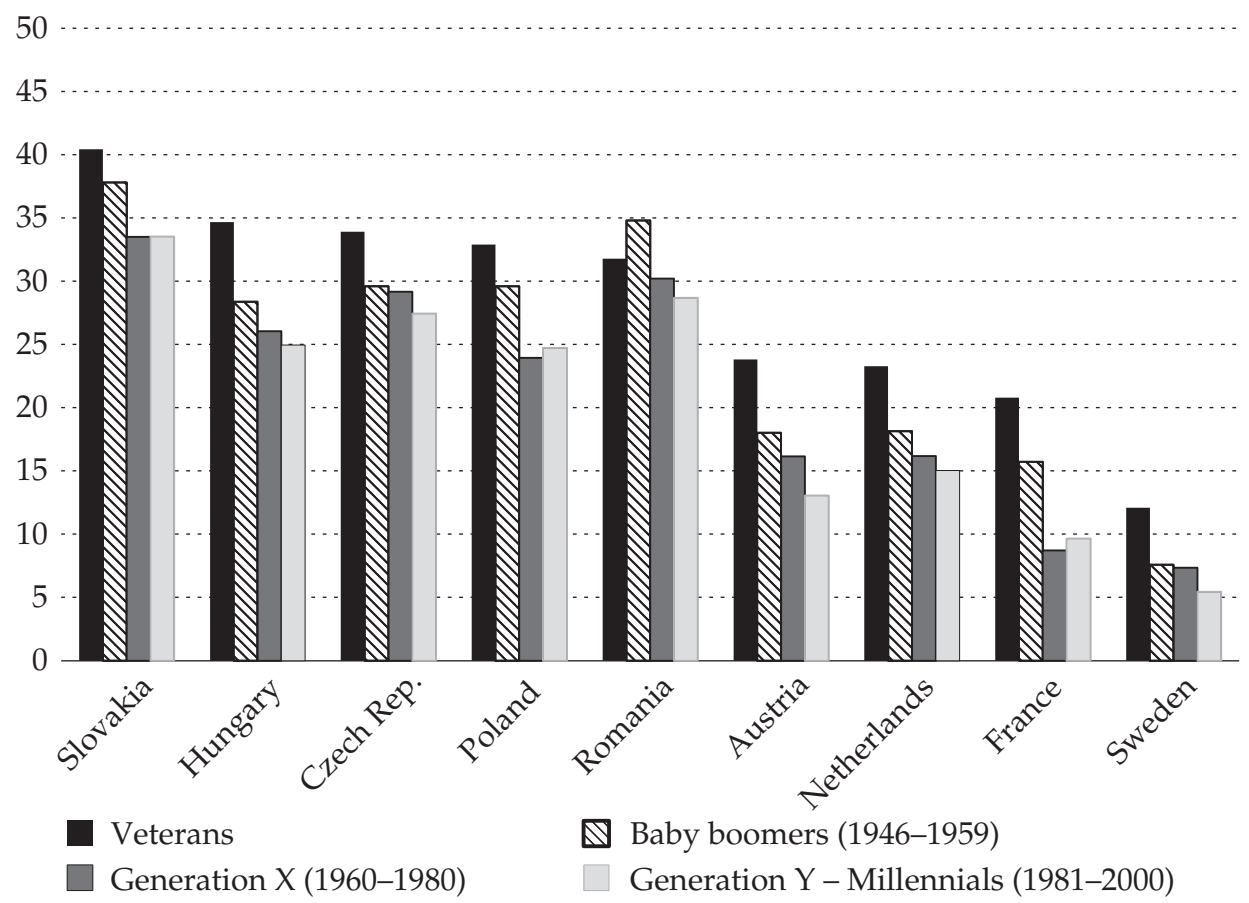

Source: EVS 2nd release EVS Cross-Sectional Data 2018.

Note: The index takes values from 0 to 100 , where 0 means no societal segregation and 100 means societal segregation.

Based on these four items, we created an index ranging from 0 to 100, where 0 means that a respondent has no gender stereotypes on a societal level while 100 indicates total gender stereotypes. As various indicators reveal, the highest values for this gender segregation index are among the respondents from the former state-socialist countries (and mainly in Slovakia - see Figure 9); in the Western European countries, the average value of the index is below 20, thus indicating very low level of gender segregation, and this is reflected in the Western respondents' responses to all the gender indicators. 
Figure 11. Justification of homosexuality, abortion, and divorce
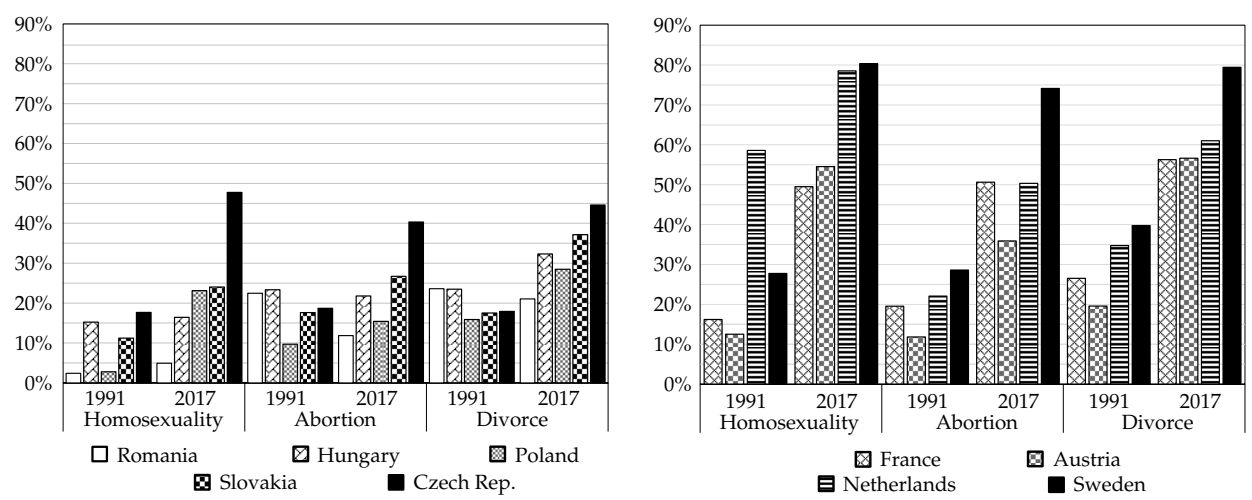

Source: EVS 2nd release EVS Cross-Sectional Data 2018.

Note: The sum of responses indicating a scale value of 8 to 10 , which means justification.

\section{Individual-choice norms}

In this section we deal with individual-choice norms. According to Inglehart, three items are indicators of these norms: abortion, homosexuality, and divorce. ${ }^{34}$ Respondents in the EVS study are asked whether they find these behaviours can be justified (referred to as acceptance further in the text). ${ }^{35}$ We will not present the complete results of each item separately owing to spatial constraints here, but we will briefly present the trends, comparing 1991 and 2017 (see Figures 11 and 12).

There are clear differences between countries with regard to the level of acceptance of some behaviours. People in Romania, Poland, Hungary, and Slovakia show the lowest level of acceptance (and in a sense also tolerance) of homosexuality, abortion, and/or divorce both in 1991 and 2017. It suggests that they retain tra-

\footnotetext{
${ }^{34}$ One might argue that 'divorce' is no longer a relevant indicator of post-modernism in the context of partnership behaviour. This objection could be based on the fact that countries in Europe have been registering considerably high divorce rates since 1991. Moreover, marriage rates have declined over the past three decades and cohabitation has become an important form of partnership that frequently replaces marriage. However, we believe that in a semantic perspective 'divorce' still symbolises the disintegration of a partnership, whether married or cohabitating. Therefore, like Inglehart, we use it in our analysis.

${ }_{35}$ The question was phrased as follows: Please tell me for each of the following whether you think it can always be justified, never be justified, or something in between, using this card. The items were measured on a 10-point scale, where a value of 1 means never justifiable and 10 means always justifiable.
} 
Table 5. Individual-choice norms in 1991-2017 (index means)

\begin{tabular}{lcccc}
\hline & 1991 & 1999 & 2008 & 2017 \\
\hline Czech Rep. & 4.7 & 5.6 & 5.4 & 6.4 \\
Slovakia & 4.2 & 4.9 & 4.9 & 5.6 \\
Hungary & 4.2 & 3.3 & 4.6 & 4.7 \\
Poland & 3.1 & 3.7 & 3.5 & 4.3 \\
Romania & 3.8 & 3.4 & 3.5 & 3.3 \\
\hline
\end{tabular}

\begin{tabular}{lcccc}
\hline & 1991 & 1999 & 2008 & 2017 \\
\hline Sweden & 5.4 & 7.6 & 8.0 & 8.5 \\
Netherlands & 6.2 & 6.7 & 6.5 & 7.8 \\
France & 4.9 & 5.8 & 6.1 & 6.9 \\
Austria & 4.0 & 5.3 & 5.3 & 6.8 \\
& & & & \\
\hline
\end{tabular}

Source: EVS integrated 1981-2008 and EVS 2nd release EVS Cross-Sectional Data 2018. Index takes values from 1 to 10 - a value of 1 means no support for individual-choice norms (traditional view) and a value of 10 means support for individual-choice norms (modern view).

Note: Countries are ranked by means in 2017.

ditional attitudes on this dimension of modernity. In contrast, people in Sweden and the Netherlands have very high levels of acceptance, which indicates (post) modern individual-choice attitudes. The Czech Republic, the most tolerant of the CEE countries in its views on these behaviours, is similar to Austria and France. These three countries are somewhere in the middle, which indicates mild modern individual-choice attitudes.

For more a comprehensive picture, we created an index based on these three items. Its scale ranges from 1 to 10: value 1 means no support for individual-choice norms (traditional view) and 10 means support for and tolerance of

Figure 12. Regression of the Human Development Index and the index of individual-choice norms in 1991 (panel A) and 2017 (panel B)
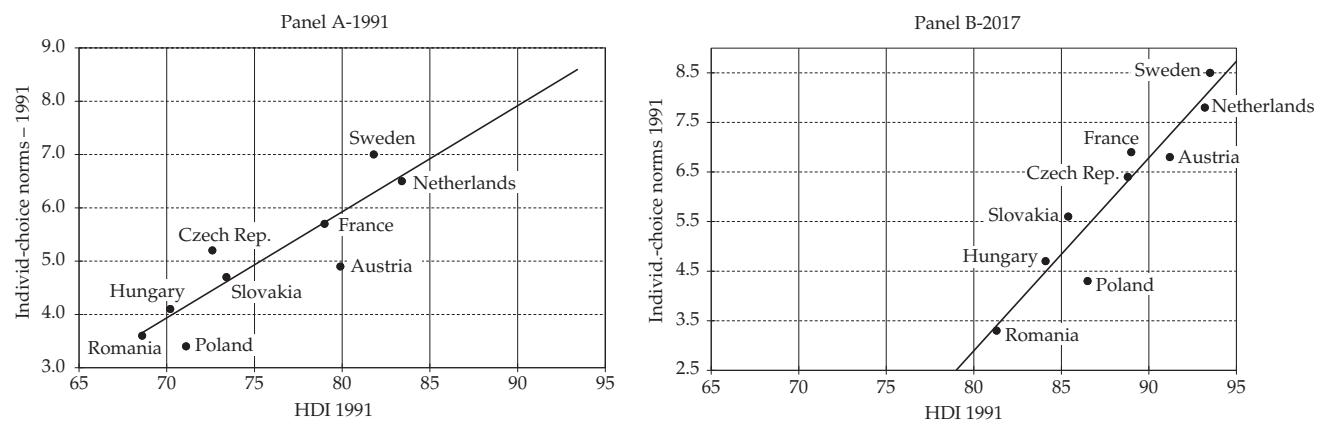

Source: EVS 2nd release EVS Cross-Sectional Data 2018. 
Figure 13. Individual-choice norms index - acceptance - at the country level and by generations in 1991-2017 (means)—first part
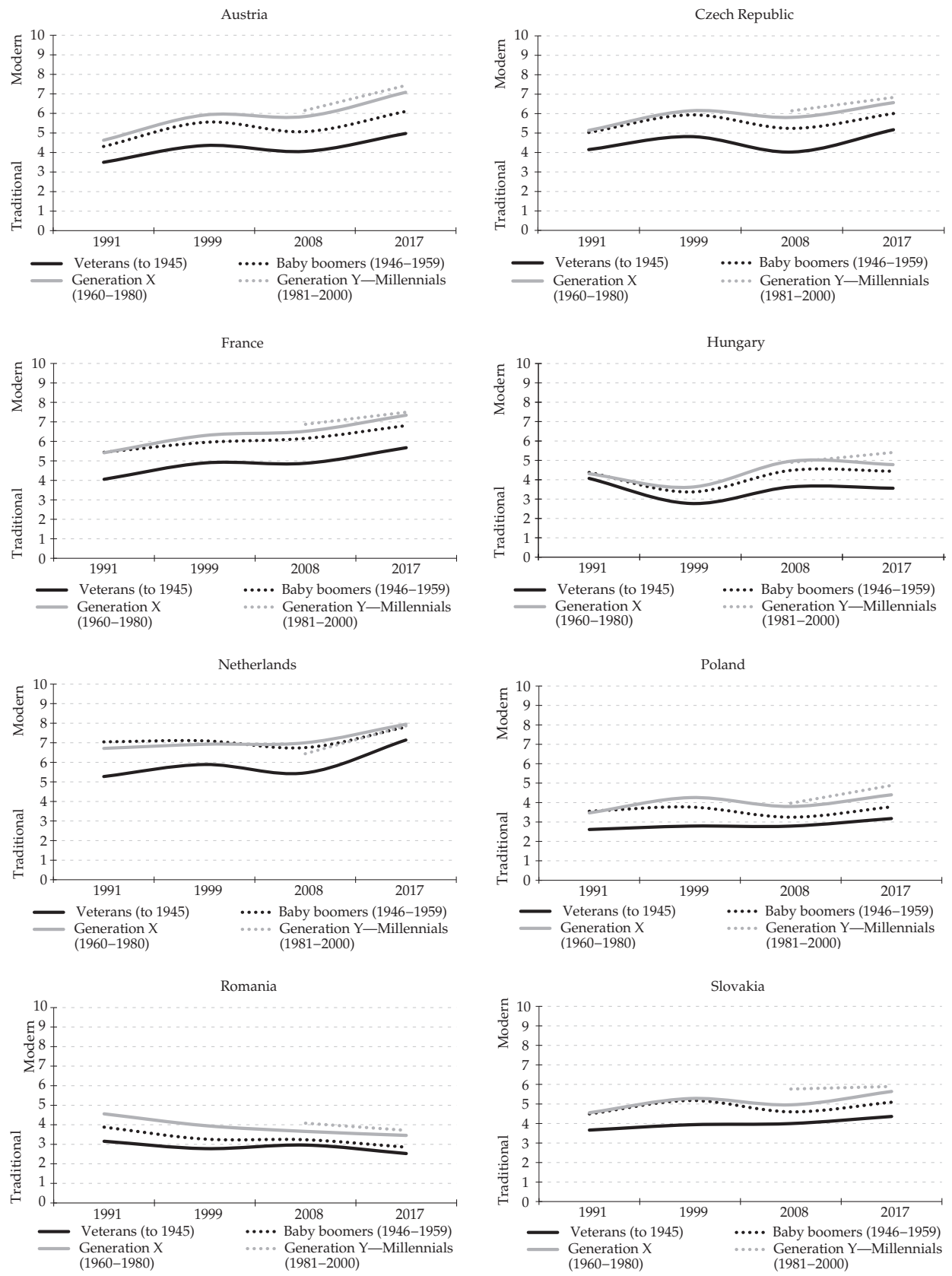
Figure 13. Individual-choice norms index-acceptance-at the country level and by generations in 1991-2017 (means)-second part

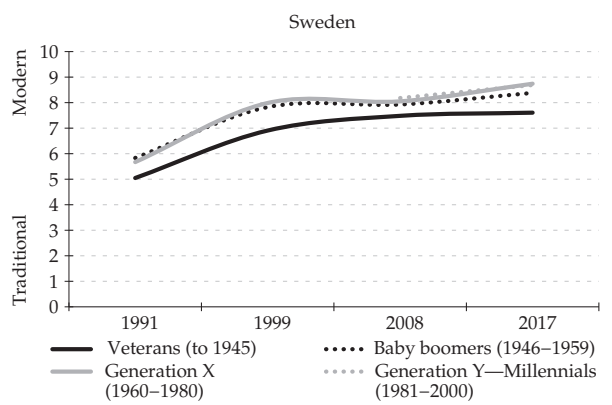

Source: EVS integrated 1981-2008 and EVS 2nd release EVS Cross-Sectional Data 2018.

Note: The index takes values from 1 to 10 , where a 1 means no justification (traditional view) and 10 means full justification (modern view). Data for Generation Y only for 2008 and 2017.

individual-choice norms (modern view). The average values of this index in each country and by wave are presented in Table 5. As was the case for individual items, we can, logically, observe clear differences between CEE and Western European countries. People in the CEE countries endorse traditional views (Czechia is the exception), while people in the Western countries favour modern views. Sweden has the highest support for modern individual-choice norms, while Romania has the highest support for traditional views. Views in the Czech Republic are very close to those in Austria and France. Support for modern individualchoice norms - in accordance with modernisation theory - increased in all countries between 1991 and 2017 except Romania, where it slightly decreased.

Human development, as measured by the HDI, quite clearly intervenes in the overall acceptance / non-acceptance of homosexuality, abortion, and divorce. As Figure 12 shows, at the aggregate level, a higher degree of human development is also associated with a higher acceptance of these phenomena. This is particularly noticeable in 2017, when with each HDI increase of one tenth of a point (on a scale from 0 to 1 ), the index of individual-choice norms increases by 0.4 points on a scale from 1 to 10 (in 1991 it was 0.2).

As far as the generational differences are concerned (see Figure 13), they follow the expected pattern. The older people are (i.e. being a member of an older generation), the more traditional the individual-choice norms they support. And vice versa: the younger people are, the more modern the attitudes they hold.

\section{Conclusion and discussion}

In this exploratory article, we inquired into the effects of modernisation and intergenerational population change on value structures. We based our research on Inglehart's (and his colleagues') ideas about the relationships between the economic and social modernisation of societies and the culture shift conceptu- 
alised as profound changes in people's value structures. To make our inquiry manageable, we focused on three dimensions of cultural shift: the development of post-materialism, trends in attitudes towards gender equality, and trends in individual-choice norms. An important dimension of our research was also to track whether the assumed value changes were in accordance with Inglehart's socialisation hypothesis that in modernising societies the youngest generations are primarily the bearers of new value priorities. Thanks to the longitudinal character of our data, we were able to look at different generations and check whether the younger generations in CEE countries, who were socialised and grew up after 1989 in a time of rapid economic and political changes, show higher levels of postmodern values than the generations socialised during the communist regime.

Our basic assumption was that given that the selected CEE countries have made relatively rapid progress in political and economic development since 1990, by 2017 we should be able to find attitudes and value structures in these countries that are relatively similar to ones that have been observed in the Western part of Europe. To put it simply, we wanted to see whether the value shifts in CEE countries have followed the modernisation path and copied the trends observed in Western European countries, and to examine whether Inglehart's modernisation theory can be applied to the former communist countries that have been developing from totalitarian states and command economies into standard democratic capitalist societies.

Does Inglehart's theory work in CEE countries? The answer is yes and no. The affirmative answer covers the assumption of the effects of intergenerational population change. In every sphere of cultural modernisation we analysed, i.e. post-materialism, gender roles, and individual-choice norms, we found differences in values and attitudes among generations: the older generations were always more traditional in their answers to survey questions than the younger generations. This was not only true in the CEE countries; we recorded the same trend in the Western European countries. Thus, one important assumption of modernisation theory cannot be refuted, which is that as social change (modernisation) progresses, new value preferences - resulting from generational replacement - will prevail, while the original preferences will begin to fade away with the outgoing generations.

As for the assumption that with socioeconomic modernisation come higher shares of post-materialism, more gender-egalitarian attitudes, and stronger support for individual-choice norms, the results are not so clear-cut. We saw that in the CEE countries, in line with modernisation theory, there was only a moderate increase in post-materialism between 1991 and 2017 in Slovakia (from 6\% to 10\%) and in the Czech Republic ( $6 \%$ to $13 \%$ ), a considerable increase in Hungary (from $4 \%$ to $17 \%$ ), and a large increase in Poland (from 10\% to 26\%). The exception was Romania, where the share of post-materialists remained low (from $7 \%$ to $10 \%$ ). Nevertheless, the shares of post-materialists in the CEE countries in 2017 were still much lower than the shares in the Western countries, where they ranged 
between $18 \%$ and $24 \%$ in 2017. However, in the Western countries, the trend in the proportions of post-materialists was unstable between 1991 and 2017 and the key finding is that the shares of post-materialists - with the exception of the Netherlands - remained essentially the same. In the Netherlands, the data indicate that level of post-materialism even decreased in the studied period by almost a half (from $33 \%$ to $18 \%$ ).

The results for the Western European countries present an interesting finding: although the Western countries we analysed are among the most developed in the world, the share of post-materialism in these countries has not increased over the last 25 years, even though the indicators of socioeconomic development point to improvement. This raises an important question: Is the way that post-materialism is measured valid? Does the method of measurement suggest that, after a certain level of socioeconomic development, higher levels of post-materialism are not identified and the relationship between socioeconomic development and post-materialism loosens and is no longer valid? Figure $2 b$ would strongly support this conclusion.

In the CEE countries, we found the predicted trend in attitudes towards the issues indicating gender equality. From 1991 to 2017, the initially very high proportions of people found to express traditional and gender-stereotypical attitudes de facto linearly decreased towards gender equality attitudes. Here, therefore, socioeconomic and value developments are moving in the expected direction. However, even in 2017, the CEE countries were far from reaching the level of gender-equality attitudes recorded in Western countries. In the Western countries, there was a linear decline in traditional gender attitudes in the 1991-2017 period, but the starting point in 1991 was already much lower than in the CEE countries. With a little exaggeration, we could even say that in 2017 the CEE countries reached the point where the Western countries had set out from in 1991. It is evident that in the CEE countries the gender revolution is still in progress. From a generational point of view, the survey data indicate that Western generations born after 1960 have already internalised modern gender-role attitudes and have thus more or less completed the gender revolution.

Within individual-choice norms indicated by attitudes towards homosexuality, abortion, and divorce we found - as with gender attitudes - clear differences between the CEE and the Western European countries. Although the support for modern individual-choice norms increased in all the CEE countries between 1991 and 2017 (except in Romania, where it slightly decreased), we still find that people tend to endorse traditional views (the Czech Republic is the exception). Among the Western countries, Sweden had the highest support for modern individual-choice norms in 2017. In this sphere of modernity, there seems to be a clear pattern: the more advanced countries are in terms of human development, the more they support individual-choice norms.

How should we understand our overall results? When we started our analysis, we expected to find considerable differences in attitudes and values between 
East and West in 1991. This was confirmed. We also assumed that by 2017 the value differences between the Eastern and Western European countries would decrease and that there would be some convergence. That did not happen. We must agree with Inglehart, Ponarin and Inglehart [2017: 1317] who warned that '...in short, when a society attains high levels of existential security and people grow up taking survival for granted, rapid cultural changes can occur-but this happens with a multi-decade time lag between when secure conditions emerge and new norms predominate'. Even though the EVS has data covering a quarter of a century, it seems that that is still not enough time for the value structures of the former communist and the traditional democratic countries to draw closer together. It is true, as we have confirmed, that there are cultural differences between generations in societies. But a substantive change requires enough time for the attitudes and values of new generations to prevail in society. We agree with Esmer's [2007: 86] assertion that modernisation has indeed had an impact on values 'in a predicted direction, but the magnitude and occasionally even the direction of the influence will depend on cultural heritage'. Cultural legacies change through both intergenerational replacement and historical period influence. Savelyev [2016] has demonstrated that the post-materialist values observed in CEE countries (and not only) are determined more by both cohort replacement and within-cohort effects. Whether in CEE countries this involves intergenerational replacement or historical period influence must yet be demonstrated in further analyses. We argue that it is a combination of both intergenerational replacement and historical period influence.

Inglehart and Bakker [2000] were aware of this, noting that modernisation does not necessarily mean the homogenisation and convergence of cultures because cultural legacies have a role in the process. It is also important to bear in mind the fact emphasised by Diez-Nicholas [2002], who claim that new values are usually supported by the elites much sooner than they are by the masses (measured, for example, by education). We deliberately did not take this phenomenon into account in our analysis because it would have enormously increased the length of the paper. However, in a different analysis of long-term trends in EVS data we did register the effect of education. For instance, Fučík, Chromková Manea and Rabušic [2019] studied the normative aspect of motherhood and found that the share of agreement with the need for a woman to have children within the Czech female population decreases with increasing levels of education in all waves: the higher the level of education, the lower the proportion of agreement with the need for women to have children. This trend goes hand in hand with the importance of education for women and the influence of education on the emancipation and life aspirations of women. For men, this the trend was noticeable only in 1991; it was irregular in other waves and the difference between educational categories was not very large (except for 2017). Matejková and Chromková Manea [2019] checked for differences in preferred work attributes (external and internal) by education level in the Czech Republic and Slovakia and 
found that people with a university education (regardless of gender) are more likely to prefer internal work characteristics, such as the opportunity to use one's initiative at work, the possibility to achieve something, and responsible work. These internal work attributes and their preference in the population are typical for Western countries and suggest a post-materialist interpretation accompanied by economic, political, and social development.

In our paper, we found that the Western and Eastern European countries we compared still differ in their value preferences - in some cases less, in others more - even though they are all members of the EU and are part of a globalisation process that should contribute to value homogenisation. In this light it is necessary to ask an important question: Which of the two theses of modernisation will be fulfilled over time - the classical one, which presupposed the convergence of industrial societies, or the opposite one formulated by Shmuel Eisenstadt [2000]; who claims that modernisation development is moving towards 'multiple modernities', i.e. modernities that 'do share some common characteristics but that at the same time they develop great differences between them - not just local variations, but indeed differences with respect to the core characteristics of modernity' [Eisenstadt 2006: 199]. We cannot provide a clear answer at present. However, our results offer partial support for the classical theory of increasing similarity between CEE and Western countries. At the same time, however, we believe that in 2026, when a new wave of EVS data will be collected, it will be possible to present empirical evidence showing the direction in which the modernisation of CEE countries has headed: whether towards the value convergence of the Eastern and Western parts of Europe and towards the efforts to build a common European Union identity, or towards multiple modernities, in which collective identities are continually reconstructed in relation to the new global context [Eisenstaddt 2000: 21].

Beatrice-Elena Chromková Manea is a researcher at the Department of Sociology, Faculty of Social Studies of Masaryk University in Brno. She mainly specialises in topics relating to the issue of population studies and value changes. Her other research interests include well-being and health. She is the co-author and co-editor of the books Rodičovské dráhy (2015) and Odděleně spolu? Česko a Slovensko optikou vývoje hodnot po roce 1991 (2019).

LADISLAV RABUŠIC is a professor at the Department of Sociology, Faculty of Social Studies of Masaryk University in Brno. His research is mainly focused on population studies and value changes. He is the author of dozens of articles and a number of chapters in books published both in the Czech Republic and abroad. He is the Czech representative in the Council of Program Directors of the European Values Study Consortium. 


\section{References}

Abramson, P. R. and R. Inglehart. 1992. 'Generational Replacement and Value Change in Eight West European Societies.' British Journal of Political Science 22 (2): 183-228, https://doi.org/10.1017/S0007123400006335.

Abramson, P. R., and R. Inglehart. 1994. 'Education, Security, and Postmaterialism: A Comment on Duch and Taylor's 'Postmaterialsm and the Economic Condition.' American Journal of Political Science 38 (August): 797-814.

Beere, C. A. 1990. Gender Roles: A Handbook of Tests and Measures. Westport, CT: Greenwood Press.

Cates, S. V. 2010. 'Generational Management in Corporate America: The Differences and Challenges in Management of Four Generations of Working Adults.' Chinese Business Review 9 (8): 46-54.

Datler, G., W. Jagodzinski and P. Schmidt. 2013. 'Two Theories on the Test Bench: Internal and External Validity of the Theories of Ronald Inglehart and Shalom Schwartz.' Social Science Research 42 (3): 906-925, https://doi.org/10.1016/j.ssresearch.2012.12.009.

Diez-Nicholas, J. 2002. 'Two Contradictory Hypotheses on Global Governance: Societal Convergence or Civilization Difference and Clash.' Comparative Sociology 1 (3-4): 465-494, https://doi.org/10.1163/156913302100418547.

Domeyer, D. 2006. 'How to Get the Most from a Multigenerational Workforce.' OfficePRO 66: $14-16$.

Duch, R. M. and M. A. Taylor. 1993. 'Postmaterialism and the Economic Condition.' American Journal of Political Science 37 (3): 747-779, https://doi.org/10.2307/2111573.

Duch, R. M., and M. A. Taylor. 1994. 'A Reply to Abramson and Inglehart's 'Education, Security, and Postmaterialism." American Journal of Political Science 38 (August): 815-24.

Durkin, D. 2007. 'Engaging Four Generations to Enhance Productivity.' Chief Learning Officer 6 (3): 30-35.

Eisenstadt, S. N. 2000. 'Multiple Modernities.' Daedalus 129 (1) 1-29, https://doi.org/10.1177/03058298000290031201.

Eisenstadt, S. N. 2006. 'Multiple Modernities in the Framework of a Comparative Evolutionary Perspective.' Pp. 199-218 in Understanding Change. Models, Methodologies, and Metaphors, edited by A. Wimmer and R. Kassler. Basingstoke, UK: Palgrave Macmillan, https://doi.org/10.1057/9780230524644_14.

Esmer, Y. 2007. 'Globalization, “McDonaldization" and Values: Quo Vadis?' Pp. 79-98 in Measuring and Mapping Cultures. 25 Years of Comparative Value Surveys, edited by E. Yilmaz and T. Petterson. Leiden and Boston, MA: Brill, https://doi.org/10.1163/ej.9789004158207.i-193.33.

Esping-Andersen, G. 1990. The Three Worlds of Welfare Capitalism. Princeton, NJ: Princeton University Press, https://doi.org/10.1177/095892879100100108.

Flanagan, S. C. 1980. 'Value Cleavages, Economic Cleavages, and the Japanese Voter.' American Journal of Political Science 24 (2): 177-206, https://doi.org/10.2307/2110862.

Flanagan, S. C. 1982. 'Measuring Value Change in Advanced Industrial Societies:

A Rejoinder to Inglehart.' Comparative Political Studies 15 (1): 99-128, https://doi.org/10.1177/0010414082015001005.

Flanagan, S. C. and A.-R. Lee. 2003. 'The New Politics, Culture Wars and the Authoritarian-Libertarian Value Change in Advanced Industrial Democracies.' Comparative Political Studies 36 (3): 235-270, https://doi.org/10.1177/0010414002250664. 
Fučík, P., B.-E. Chromková Manea and L. Rabušic. 2019. 'K problému deinstitucionalizace manželství.' (On the de-institutionalisation of marriage) Pp. 33-60 in Odděleně spolu?: Česko a Slovensko optikou vývoje hodnot po roce 1991, edited by L. Rabušic, Z. Kusá, B.-E. Chromková Manea and K. Strapcová. 1st ed. Bratislava: Slovart.

Glass, A. 2007 'Understanding Generational Differences for Competitive Success.' Industrial and Commercial Training 39 (2): 98-103, https://doi.org/10.1108/00197850710732424.

Hadenius, A. and J. Teorell. 2005. 'Cultural and Economic Prerequisites of Democracy: Reassessing Recent Evidence.' Studies in Comparative International Development 39 (4): 87-106, https://doi.org/10.1007/BF02686166.

Haller, M. 2002. 'Theory and Method in the Comparative Study of Values: Critique and Alternative to Inglehart.' European Sociological Review 18 (2): 139-158, https://doi.org/10.1093/esr/18.2.139.

Hernaus, T. and N. Pološki Vokic. 2014. 'Work Design for Different Generational Cohorts: Determining Common and Idiosyncratic Job Characteristics.' Journal of Organizational Change Management 27 (4): 615-641, https://doi.org/10.1108/JOCM-05-2014-0104.

Human Development Report 2010. United Nations Development Programme: New York. Retrieved 19 October 2008 (http://hdr.undp.org/sites/default/files/reports/270/ hdr_2010_en_complete_reprint.pdf).

Inglehart, R. 1971. 'The Silent Revolution in Europe: Intergenerational Change in Post-industrial Societies.' American Political Science Review 65 (4): 991-1017, https://doi.org/10.2307/1953494.

Inglehart, R. 1977. The Silent Revolution. Changing Values and Political Styles in Advanced Industrial Society. Princeton, NJ: Princeton University Press.

Inglehart, R. 1981. 'Post-Materialism in an Environment of Insecurity.' American Political Science Review 75 (4): 880-900, https:// doi.org/10.2307/1962290.

Inglehart, R. 1982. 'Changing Values in Japan and the West.' Comparative Political Studies 14 (4): 445-479, https://doi.org/10.1177/0010414082014004002.

Inglehart, R. 1990. Culture Shift in Advanced Industrial Societies. Princeton, NJ: Princeton University Press, https://doi.org/10.1515/9780691186740.

Inglehart, R. 1997. Modernization and Postmodernization. Princeton, NJ: Princeton University Press.

Inglehart, R. F., E. Ponarin and R. C. Inglehart. 2017. 'Cultural Change, Slow and Fast: The Distinctive Trajectory of Norms Governing Gender Equality and Sexual Orientation.' Social Forces 95 (4): 1313-1340, https://doi.org/10.1093/sf/sox008.

Inglehart, R. and W. Baker. 2000. 'Modernization, Cultural Change and the Persistence of Traditional Values.' American Sociological Review 65 (1): 19-51, https://doi.org/10.2307/2657288.

Inglehart, R. and P. Norris. 2003. Rising Tide: Gender Equality and Cultural Change around the World. Cambridge: Cambridge University Press, https://doi.org/10.1017/CBO9780511550362.

Inglehart, R. and C. Welzel. 2005. Moderization, Cultural Change, and Democracy. The Human Development Sequence. Cambridge: Cambridge University Press.

Inglehart, R. 2018. Cultural Evolution: People's Motivations are Changing, and Reshaping the World. Cambridge: Cambridge University Press. doi:10.1017/9781108613880.

Kalmijn, M. 2003. 'Country Differences in Sex Roles Attitudes: Cultural and Economic Explanations.' Pp. 311-337 in The Cultural Diversity of European Union, edited by W. Arts, J. Hagenaars and L. Halman. Leiden and Boston, MA: Brill.

Kupperschmidt, B. R. 2000. 'Multigeneration Employees: Strategies for Effective 
Management.' Health Care Manager 19 (1): 65-76, https://doi.org/10.1097/00126450-200019010-00011.

Mannheim, K. 1952. Essays on the Sociology of Knowledge. London: Routledge \& Kegan Paul.

Matejková, A. and B.-E. Chromková Manea. 2019. 'Muži, ženy a práca : rodové rozdiely v preferenciách jednotlivých atribútov práce.' (Men, women and work: gender differences in preferred job attributes) Pp. 151-177 in Odděleně spolu?: Česko a Slovensko optikou vývoje hodnot po roce 1991, edited by L. Rabušic, Z. Kusá, B.-E. Chromková Manea and K. Strapcová. Bratislava: Slovart, https://doi.org/10.34135/svpmvpIV.191027.

PrincetonOne. 2013. 'Understanding Generation Y - What You Need to Know about the Millennials.' Working Paper PrincetonOne. Skillman, NJ. Retrieved 1 October 2018 (www.princetonone.com/news/PrincetonOne\%20White\%20Paper2.pdf).

Rabušic, L. 2000. 'Je česká společnost 'postmaterialistická?' (Is Czech society postmaterialistic?) Sociologický časopis 36 (1): 3-22, https://doi.org/10.13060/00380288.2000.36.1.02.

Rokeach, M. 1973. The Nature of Human Values. New York: Free Press.

Savelyev, Y. 2016. 'Decomposition of Value Change in European Societies in 1995-2008: Test of Modernization Model and Socialization Hypothesis.' Sociologia 48: 267-289.

Van Deth, J. W. 1983. 'The Persistence of Materialist and Post-Materialist Value Orientations.' European Journal of Political Research 11 (1): 63-79, https://doi.org/10.1111/j.1475-6765.1983.tb00043.x.

Van der Horst, M. 2014. 'Gender Role Attitudes.' Pp. 2451-2453 in Encyclopedia of Quality of Life and Well-Being Research, edited by A. C. Michalos. Dordrecht: Springer Science, https://doi.org/10.1007/978-94-007-0753-5_1135.

Venus, M. 2011. 'The Multi-generational Workplace - How Employers Can Help Silents, Boomers, Gen Xers and Millennials Work Together.' Northern Colorado Business Report Diversity Supplement: 7-10.

Voicu, M. and B. Voicu. 2002. "Gender values dynamics. Towards a common European pattern?", Romanian Journal of Sociology, XIII (1-2): 42-63.

Voicu, B. 2008. 'Between tradition and postmodernity? A dynamic of the value orientations in Romanian: 1993-2005', in Voicu, B., Voicu, M., (eds.), The Values of the Romanians: 1993-2006. A Sociological Perspective, Iaşi, Institutul European, 2008, pp. 271-318, available online at http://web.bogdanvoicu.ro/uploads/The_Values_of_ Romanians_corect2_28-07-08.pdf .

Yang, Y. and K. C. Land. 2008. 'Age-Period-Cohort Analysis of Repeated Cross-section Surveys - Fixed or Random Effects?' Sociological Methods and Research 36 (3): 297-326, https://doi.org/10.1177/0049124106292360. 